\title{
A Systematic Review of the Relationship Between Energy Consumption and Economic Growth in GCC Countries
}

\author{
Mohammed AlKhars ${ }^{1, *} \mathbb{C}$, Fazlul Miah ${ }^{2} \mathbb{D}$, Hassan Qudrat-Ullah ${ }^{1}$ and Aymen Kayal ${ }^{3}$ \\ 1 Department of Information Systems and Operations Management, KFUPM Business School, Dhahran 31261, \\ Saudi Arabia; hassan.qudratullah@kfupm.edu.sa \\ 2 Department of Accounting and Finance, KFUPM Business School, Dhahran 31261, Saudi Arabia; \\ fmiah@kfupm.edu.sa \\ 3 Department of Management and Marketing, KFUPM Business School, Dhahran 31261, Saudi Arabia; \\ akayal@kfupm.edu.sa \\ * Correspondence: malkhars@kfupm.edu.sa; Tel.: +966-13-860-7744
}

Received: 12 March 2020; Accepted: 1 May 2020; Published: 8 May 2020

\begin{abstract}
This survey study analyzed the existing literature on the relationship between energy consumption and economic growth in the six Gulf Cooperation Council (GCC) countries (Saudi Arabia, United Arab Emirates, Bahrain, Qatar, Oman and Kuwait). This study identified 59 articles published in 18 journals covering the period 2006-2019. The articles were grouped into two categories: the first category included studies analyzing the energy-growth relationship at the individual country level while the second category included studies analyzing the relationship at a multi-country level. The result of this study revealed that $18 \%$ of the observations supported the growth hypothesis, $26 \%$ supported the conservation hypothesis, $43 \%$ supported the feedback hypothesis and $13 \%$ supported the neutral hypothesis. As our analysis found a dominant support for the growth and feedback hypotheses, this implies that the focus of energy policies in GCC countries has been on the supply and the uninterrupted availability for the expansion and growth of their industrial and developmental activities. However, for a sustainable development and growth of the GCC economies and meeting the environmental challenges, there is an urgent need for the expansion of renewable energy technologies in the energy supply mix of GCC countries.
\end{abstract}

Keywords: energy consumption; economic growth; GCC; literature review

\section{Introduction}

Energy conservation is an important macroeconomic policy issue for many governments including Gulf Cooperation Council (GCC) countries. However, there is a debate on the relationship between energy consumption and economic growth and the results are inconclusive. The literature on the relationship between energy consumption and economic growth (energy-growth nexus) is enormous and several survey papers in the global context have been conducted over the years [1-7]. Payne's [1] study focused on the causal relationship between electricity consumption and economic growth of 34 studies. Ozturk [2] had separate sections for the energy-growth nexus and the electricity-growth nexus. His study surveyed 38 individual country-specific studies and 26 multi-country studies for the energy-growth relationship. Menegaki [3] conducted a meta-analysis on the relationship between energy consumption and gross domestic product (GDP). They included 51 studies published during the last two decades in the paper. Kalimeris et al. [4] also conducted a meta-analysis investigating this relationship on a larger scale. They included 158 studies covering the period 1978-2011. Omri [5] provided an international literature survey on four energy-growth nexus: 
energy-growth, electricity-growth, nuclear-growth and renewable-growth. His study analyzed 48 individual country-specific studies on the energy-growth nexus. Tiba and Omri [6] summarized the literature of the relationship between energy, the environment and economic growth. They surveyed 100 studies on individual countries and 80 studies on a group of countries on the energy-economic growth covering the period 1978-2014. Moreover, they identified 33 studies on individual countries and 28 studies on groups of countries on the relationship between energy, the environment and economic growth. Finally, Waheed et al. [7] surveyed the literature on economic growth, energy consumption and carbon emission by including studies published until 2019. Their study included 31 articles on the energy-growth nexus. More recently, Narayan [8] reexamined the causality relationship between energy consumption and economic growth through the predictability framework, using the panel data predictive regression model for 135 countries.

In the literature, the relationship between energy consumption and economic growth is categorized into four hypotheses:

1. Growth hypothesis: in this category, the energy consumption causes economic growth. Therefore, any conservation policy will have a negative impact on the economic growth of the country.

2. Conservation hypothesis: contrary to the growth hypothesis, the economic growth causes an increase in the energy consumption. Under this hypothesis, any energy conservation policy such as increasing the tariff will not have a negative impact on economic growth.

3. Feedback hypothesis: the relationship between energy consumption and economic growth is bidirectional meaning that energy consumption leads to economic growth, and economic growth leads to an increase in energy consumption.

4. Neutrality hypothesis: there is no causal relationship between energy consumption and economic growth.

Before implementing any conservation policy, the relationship between energy consumption and economic growth should be studied thoroughly. If the results of the investigation support the conservation hypothesis or the neutrality hypothesis, then the conservation policy will have no or minimal negative impact on economic growth. However, if the results support the growth hypothesis or the feedback hypothesis, then implementing a conservation policy will have a negative impact on the economic growth. GCC countries have been aware of the importance of energy conservation policies and therefore they have some policies in place to conserve energy consumption. For example, Saudi Arabia has recently adopted policies, regulations and plans to reduce $\mathrm{CO}_{2}$ emissions while addressing its growing demand for energy [9]. The three recently activated organizations-Clean Development Mechanism Designated National Authority, Saudi Energy Efficiency Center, and King Abdullah City for Atomic and Renewable Energy-were all mechanisms designed to address energy conservation as well as sustainable development in Saudi Arabia. Similarly, the Supreme Council of Energy in UAE was established in 2009 and tasked with ensuring that long-term growth be powered by a sustainable energy strategy. The Council develops strategy, governance and policy frameworks promoting renewable energy, energy efficiency and environmental protection. UAE's Masdar has been working on building a $50 \mathrm{MW}$ wind-generated power plant estimated to start up in 2020. The Barakah nuclear power plant began operation to supply the UAE with 5,600 MW of electricity in 2020. Moreover, the Kuwait Institute of Scientific Research (KISR) played an essential role in the realization of Kuwait's first energy conservation code of 1983, with the implementation of energy and power-saving schemes and cost-benefit assessments of the potential impacts of the code on energy demand in the building sector. KISR's energy audits resulted in energy consumption reductions at various sites of up to 30\%. Recently, the Higher Energy Committee was set up in 2018 by the Council of Ministers and tasked with improving the coordination between and among ministries, regulatory agencies, infrastructure operators and service providers [10]. Qatar's First National Development Strategy (2011-2016) incorporated broad objectives for energy efficiency improvements in the electricity and water sectors and appointed a national champion for the environment to raise 
awareness and commitment through demonstration projects and conservation partnerships. Energy Labeling and Minimum Energy Performance Requirements for Air-Conditioners was enforced since 2013. The National Program for Conservation and Energy Efficiency (Tarsheed) is currently on its second phase and aims to significantly reduce the per capita consumption of electricity and water. Bahrain's Electricity \& Water Conservation Directorate has established and executed the Guidelines for Thermal Insulation Implementation in buildings since 1999. In 2016, the government approved two plans; the "National Energy Efficiency Action Plan" and the "National Renewable Energy Action Plan" with the aim of guiding the kingdom's transition into energy efficiency and renewable energy. Finally, Oman's Master Plan for Energy Efficiency and Conservation (EE\&C) was conducted in collaboration with the Japan International Cooperation Agency (JICA) in 2013. Currently the country is developing the Oman Energy Master Plan 2040 which aims to generate 30\% of its electricity demand from renewable energy sources by 2030. In terms of energy conservation, Oman's Supreme Council for Planning has set up a committee in 2016 to develop a comprehensive green design code to meet the requirement of the proposed unified GCC Building Code. The code was approved by the Council of Financial Affairs and Energy Resources in September 2017. In terms of renewable energy plans, all the GCC countries have ongoing targets. Saudi Arabia plans to generate $54 \mathrm{GW}$ of renewable energy by 2040. Kuwait and Oman plan to increase the share of renewable energy in the energy mix to $15 \%$ by 2030 and $30 \%$ by 2030, respectively. The UAE plans to raise its clean energy target to $44 \%$ by 2050 . Similarly, $20 \%$ of 1800 MW capacity is expected to be met by renewables in Qatar by 2030. In 2020, Bahrain is aiming to generate $5 \%$ of its energy capacity from renewable energy sources [11].

However, these conservation policies should be implemented carefully to ensure that economic growth is not affected negatively. These countries have experienced huge economic and energy growth in recent decades. For example, the average rate of electricity consumption per capita for GCC countries in the period 1971-2012 was 6.2\% [12]. GDP growth rates are also following similar trends. Figure 1 shows the electricity consumption in million Kilowatt-hours for the six countries over the period 1990-2018. Moreover, Figure 2 shows the GDP (constant 2010 US \$) over the period 1980-2018 (World Bank data). The overall growth of electricity consumption and economic growth suggest that the growth hypothesis and the feedback hypothesis are more applicable in the context of GCC than the conservation hypothesis or the neutral hypothesis.

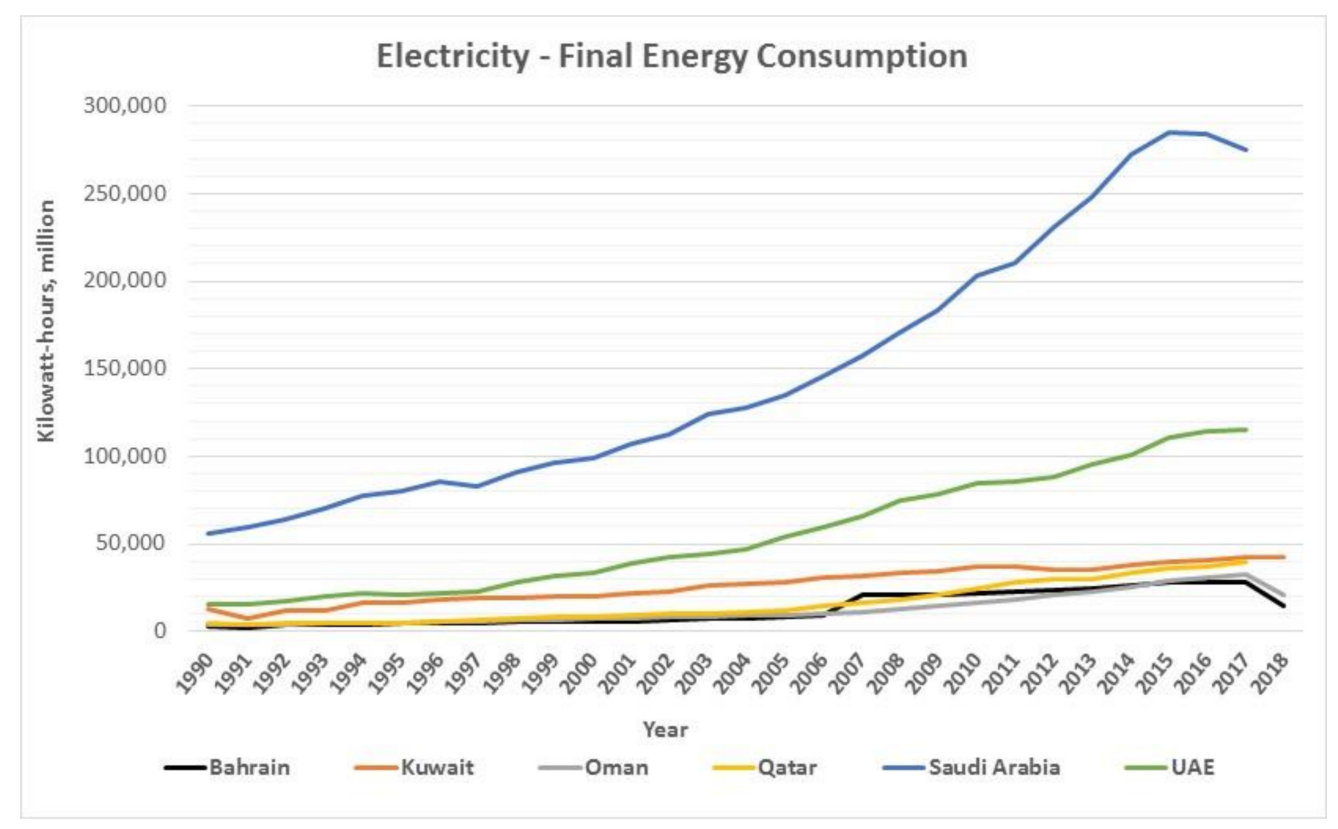

Figure 1. Electric power consumption for the six Gulf Cooperation Council (GCC) countries over the period 1990-2018. Source: UNDATA (United Nations) Available online: http://data.un.org/Data.aspx? $\mathrm{d}=$ EDATA \&f=cmID:EL;trID:12\&c=2,5,6,7,8\&s=_crEngNameOrderBy:asc,_enID:asc, yr:desc\&v=1. 


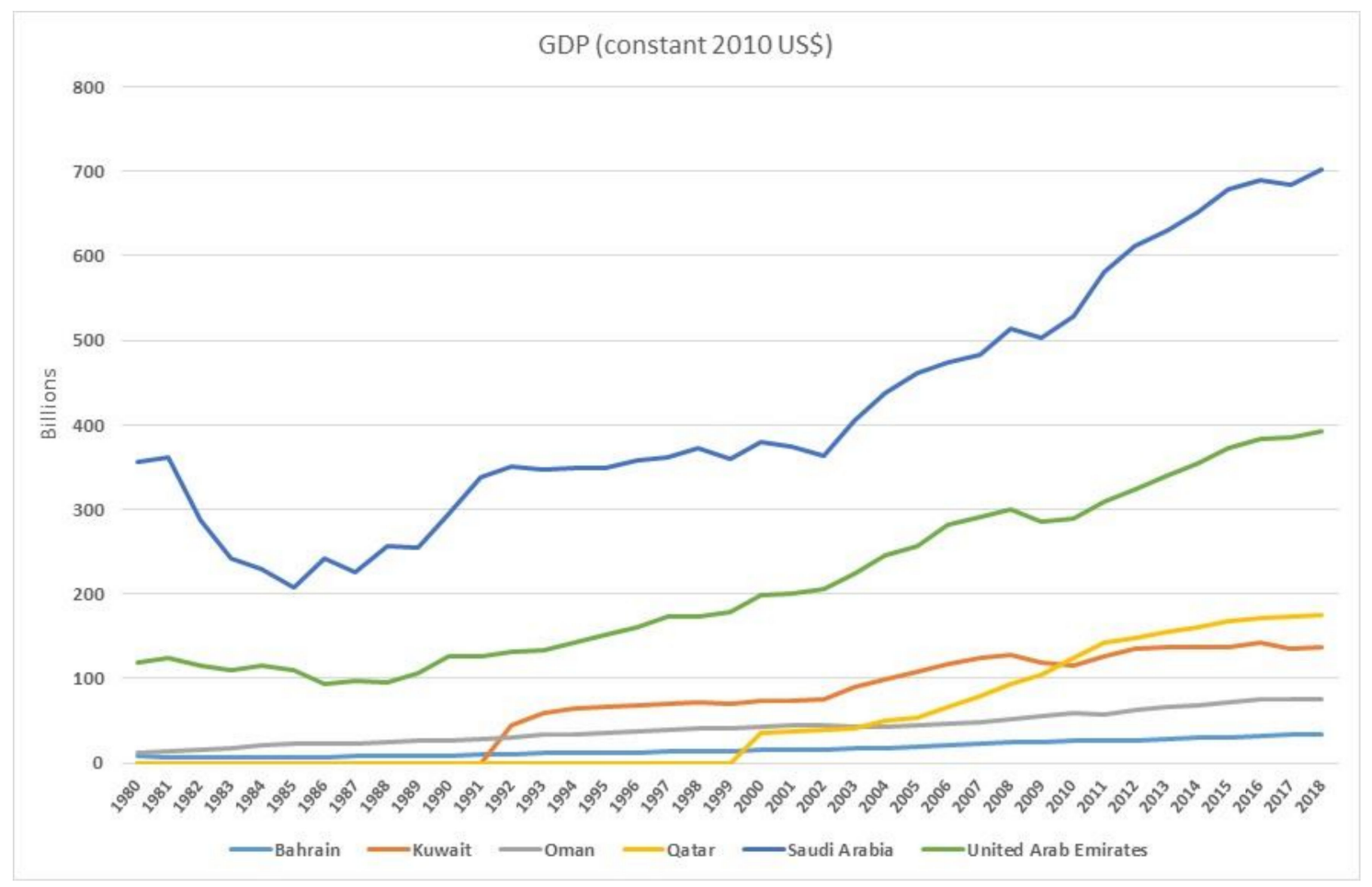

Figure 2. GDP for the six GCC countries over the period 1980-2018. Data from database: World Development Indicators. World Bank. Available online: https://databank.worldbank.org/ metadataglossary/world-development-indicators/series.

Many studies have been conducted to investigate the relationship between energy consumption and economic growth in the context of the GCC countries in its various forms (total energy, electricity, oil, natural gas etc.) during the last two decades and the literature in this area is growing each year. In order to search for articles investigating the energy-growth topic in the GCC countries, we used the citation-chasing method in which we started with a recent paper on this topic and performed an analysis of the bibliography of the references (backward citation chasing) in the paper. Moreover, we used Google Scholar to identify articles citing this recent paper (forward citation chasing). In order to ensure that only high-quality work was included in our study, we selected the identified articles that were published in the Web of Science database. Once we obtained the list of the Web of Science articles, we analyzed the articles by reading the abstract and the contents of the articles. If the articles were found to be relevant, they were included in the list. Otherwise, they were discarded. We continued this process of identifying relevant articles with each article identified from the Web of Science list using the backward and forward citation chasing. It was an exhaustive search. By the end of this search, we identified 59 articles published in 18 respected journals as shown in Table 1. The main advantage of this approach was that it helped locate as many articles related to the topic as possible. However, one possible limitation was that some articles might have been missed because of the huge number of titles checked. However, we believe that most of the articles on the GCC countries context were included in our study. Figure 3 below shows the growth of publications over the years. The first paper was published in 2006. The number of publications has increased steadily and reached a stable rate of six to eight published papers per year in the period 2013-2018. In 2019, we identified only five articles as the search ended in August 2019. We expect that more articles might be published during the remaining months of 2019. 
Table 1. No. of publications across journals.

\begin{tabular}{|c|c|c|}
\hline No. & Journal & No. of Publications \\
\hline 1 & Renewable and Sustainable Energy Reviews & 15 \\
\hline 2 & Energy Policy & 11 \\
\hline 3 & Energy Economics & 7 \\
\hline 4 & Energy & 5 \\
\hline 5 & Energy Sources, Part B: Economics, Planning, and Policy & 4 \\
\hline 6 & Economic Modelling & 3 \\
\hline 7 & OPEC Energy Review & 3 \\
\hline 8 & Sustainability & 1 \\
\hline 9 & Applied Energy & 1 \\
\hline 10 & Journal of Economics and Business & 1 \\
\hline 11 & Ecological Indicators & 1 \\
\hline 12 & Journal of the Knowledge Economy & 1 \\
\hline 13 & Renewable Energy & 1 \\
\hline 14 & South African Journal of Economics & 1 \\
\hline 15 & Environmental Science and Pollution Research & 1 \\
\hline 16 & Geosystem Engineering & 1 \\
\hline 17 & Mathematics and Computers in Simulation & 1 \\
\hline \multirow[t]{2}{*}{18} & Cogent Economics and Finance & 1 \\
\hline & Total & 59 \\
\hline
\end{tabular}

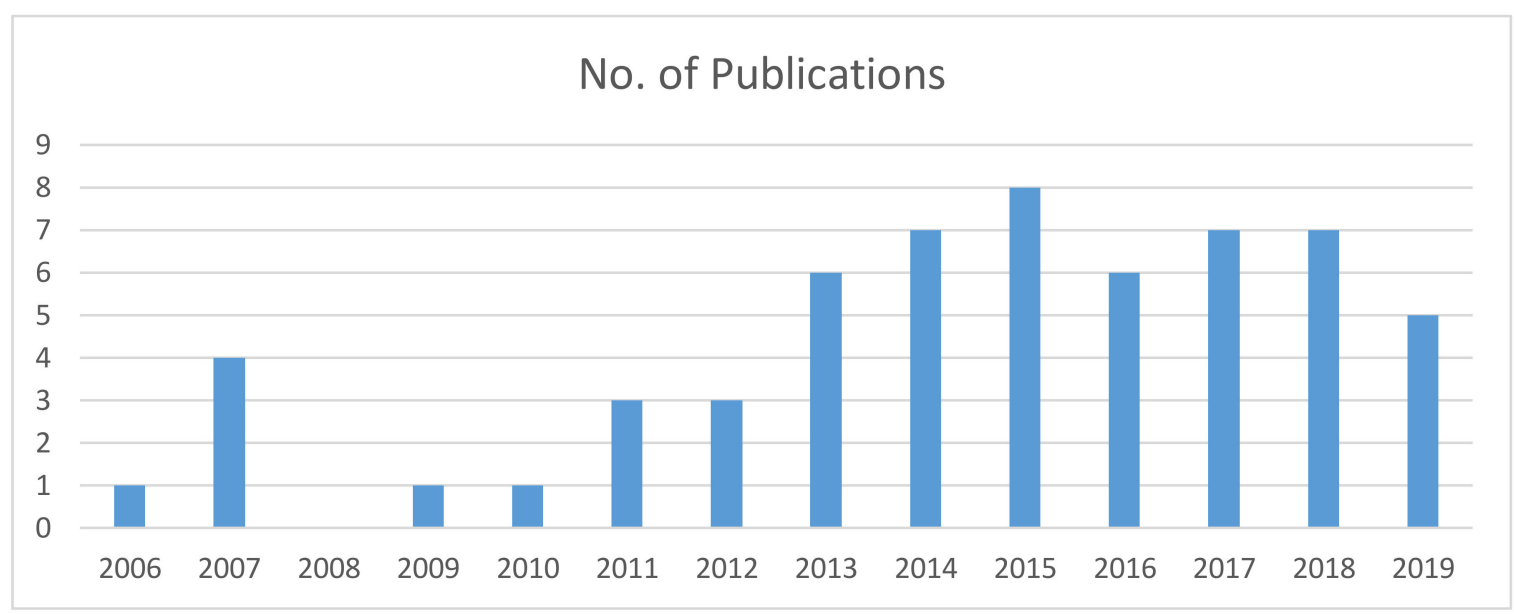

Figure 3. No. of publications by years.

To the best of our knowledge, there was no comprehensive study that critically reviewed the existing studies in the context of GCC countries. Therefore, a survey of literature on the relationship between energy consumption and economic growth focusing on the GCC countries was needed as these countries share common socioeconomic and policy challenges. This paper will fill this gap in the literature and we expect that it will help policymakers and researchers as well as promote research in the domain of energy and sustainable development in the GCC context. The remainder of the paper is organized as follows. Section 2 reviews the literature on the energy-growth relationship in the GCC countries and Section 3 provides concluding remarks. 


\section{Energy Consumption and Economic Growth Causality Literature in GCC Countries-Discussion and Analysis}

The first study on the relationship between energy consumption and economic growth was conducted by Kraft and Kraft [13] which was motivated by the high energy prices at that time. They used the US data on gross energy inputs and Gross National Product (GNP). The results supported the conservation hypothesis that GNP causes energy consumption. This study was highly influential in that it has led to the publications of several studies all around the world. These studies used different time spans, control variables, econometric methods, etc. Because of these variations, the results also varied. Some of these studies demonstrated that the causality ran from energy consumption to economic growth while others demonstrated that energy consumption caused an increase in the economic growth. Yet, other studies showed that there was no causality between these variables and the last group showed bi-directional causality running in both directions between the two variables. Table 2 provides a chronological list by date (oldest to newest) of all the 59 articles included in our study. The "Countries" column specifies the countries included in the study. Some studies included only one country such as the one by Sweidan [14]. Some other studies included more than one country such as Al-Iriani [15], which included all the GCC countries. The "No. of Observations" column counts how many times GCC countries were analyzed in the study. For example, Al-Iriani [15] studied all six GCC countries as a group. Therefore, we considered it as six observations. Squalli [16] analyzed four GCC countries on an individual basis. Therefore, four observations were counted. We did a similar count for various econometric methods used in the studies. For example, AlKhathlan and Javid [17] studied the relationship for Saudi Arabia using four different models: aggregate, oil, gas and electricity. Therefore, four observations were counted. Omri [18] analyzed the energy-growth relationship for all six GCC countries as a group and on an individual basis. Therefore, 12 observations were counted. Using these criteria, the total number of observations was 267 . We feel that the number of times that studies were performed on these countries was a good indication of the importance of the issue and of the scholarly interest on the energy-growth nexus question. Similarly, 267 was a good number of samples to draw some reliable conclusions. The period column specifies the time span of the data analyzed in the studies. For example, Al-Iriani [15] used a time span of 1971 until 2002. All 59 studies taken together, the total study time was almost 40 years. The last two columns show whether the data was analyzed on an individual country level or as a panel of a group of countries. We found that 29 studies performed panel level investigations, 28 studies performed individual country level investigations only while the remaining two studies performed both panel and individual country level investigations in the same paper. 
Table 2. Descriptions of the 59 articles included in the survey.

\begin{tabular}{|c|c|c|c|c|c|c|c|c|c|c|c|c|c|}
\hline \multirow[b]{2}{*}{ No } & \multirow[b]{2}{*}{ Study } & \multirow[b]{2}{*}{ Countries } & \multirow[b]{2}{*}{ Period } & \multirow[b]{2}{*}{$\begin{array}{c}\text { No. of } \\
\text { Observations }\end{array}$} & \multicolumn{6}{|c|}{ One or More Countries } & \multirow[b]{2}{*}{$\begin{array}{l}\text { Analyzed } \\
\text { Individually }\end{array}$} & \multirow[b]{2}{*}{$\begin{array}{l}\text { Analyzed as } \\
\text { a Group }\end{array}$} & \multirow[b]{2}{*}{ Note } \\
\hline & & & & & $\begin{array}{l}\text { Saudi } \\
\text { Arabia }\end{array}$ & Kuwait & Qatar & Oman & UAE & Bahrain & & & \\
\hline 1 & Al-Iriani [15] & GCC Countries & 1971-2002 & 6 & $\sqrt{ }$ & $\sqrt{ }$ & $\sqrt{ }$ & $\sqrt{ }$ & $\sqrt{ }$ & $\sqrt{ }$ & & $\sqrt{ }$ & \\
\hline 2 & Mehrara [19] & $\begin{array}{c}11 \text { oil-exporting countries } \\
\text { including Saudi Arabia, } \\
\text { Bahrain, Kuwait, Oman and } \\
\text { UAE }\end{array}$ & 1971-2002 & 5 & $\sqrt{ }$ & $\sqrt{ }$ & & $\sqrt{ }$ & $\sqrt{ }$ & $\sqrt{ }$ & & $\sqrt{ }$ & \\
\hline 3 & Squalli [16] & $\begin{array}{c}11 \text { OPEC countries } \\
\text { including Saudi Arabia, } \\
\text { Kuwait, Qatar and UAE }\end{array}$ & 1980-2003 & 4 & $\sqrt{ }$ & $\sqrt{ }$ & $\sqrt{ }$ & & $\sqrt{ }$ & & $\sqrt{ }$ & & \\
\hline 4 & $\begin{array}{c}\text { Mahadevan } \\
\text { and } \\
\text { Asafu-Adjaye } \\
\text { [20] }\end{array}$ & $\begin{array}{c}20 \text { net energy-importing } \\
\text { and -exporting countries } \\
\text { including Saudi Arabia and } \\
\text { Kuwait }\end{array}$ & 1971-2002 & 2 & $\sqrt{ }$ & $\sqrt{ }$ & & & & & & $\sqrt{ }$ & \\
\hline 5 & Mehrara [21] & $\begin{array}{c}3 \text { oil-exporting countries } \\
\text { including Saudi Arabia and } \\
\text { Kuwait }\end{array}$ & 1971-2002 & 2 & $\sqrt{ }$ & $\sqrt{ }$ & & & & & $\sqrt{ }$ & & \\
\hline 6 & $\begin{array}{l}\text { Narayan and } \\
\text { Smyth [22] }\end{array}$ & $\begin{array}{c}6 \text { Middle Eastern countries } \\
\text { including Saudi Arabia, } \\
\text { Kuwait and Oman }\end{array}$ & 1974-2002 & 3 & $\sqrt{ }$ & $\sqrt{ }$ & & $\sqrt{ }$ & & & & $\sqrt{ }$ & \\
\hline 7 & $\begin{array}{l}\text { Ozturk et al. } \\
{[23]}\end{array}$ & $\begin{array}{l}51 \text { countries including } \\
\text { Oman }\end{array}$ & 1971-2005 & 1 & & & & $\sqrt{ }$ & & & & $\sqrt{ }$ & \\
\hline 8 & $\begin{array}{l}\text { Al-Mulali } \\
\text { [24] }\end{array}$ & $\begin{array}{l}\text { Middle Eastern and North } \\
\text { African (MENA) countries } \\
\text { including all GCC countries }\end{array}$ & 1980-2009 & 6 & $\sqrt{ }$ & $\sqrt{ }$ & $\sqrt{ }$ & $\sqrt{ }$ & $\sqrt{ }$ & $\sqrt{ }$ & & $\sqrt{ }$ & \\
\hline 9 & $\begin{array}{l}\text { Sadorsky } \\
\text { [25] }\end{array}$ & $\begin{array}{c}\text { 8 MENA countries } \\
\text { including Saudi Arabia, } \\
\text { UAE, Bahrain, Qatar and } \\
\text { Oman }\end{array}$ & 1980-2007 & 5 & $\sqrt{ }$ & & $\sqrt{ }$ & $\sqrt{ }$ & $\sqrt{ }$ & $\sqrt{ }$ & & $\sqrt{ }$ & \\
\hline 10 & $\begin{array}{c}\text { Ozturk and } \\
\text { Acaravci [26] }\end{array}$ & $\begin{array}{l}11 \text { MENA countries } \\
\text { including Oman, Saudi } \\
\text { Arabia and UAE }\end{array}$ & 1971-2006 & 2 & $\sqrt{ }$ & & & $\sqrt{ }$ & $\sqrt{ }$ & & $\sqrt{ }$ & & $\begin{array}{l}\text { UAE: } \\
\text { assumptions } \\
\text { violated and } \\
\text { excluded }\end{array}$ \\
\hline
\end{tabular}


Table 2. Cont.

\begin{tabular}{|c|c|c|c|c|c|c|c|c|c|c|c|c|c|}
\hline \multirow[b]{2}{*}{ No } & \multirow[b]{2}{*}{ Study } & \multirow[b]{2}{*}{ Countries } & \multirow[b]{2}{*}{ Period } & \multirow[b]{2}{*}{$\begin{array}{c}\text { No. of } \\
\text { Observations }\end{array}$} & \multicolumn{6}{|c|}{ One or More Countries } & \multirow{2}{*}{$\begin{array}{l}\text { Analyzed } \\
\text { Individually }\end{array}$} & \multirow{2}{*}{$\begin{array}{l}\text { Analyzed as } \\
\text { a Group }\end{array}$} & \multirow[b]{2}{*}{ Note } \\
\hline & & & & & $\begin{array}{l}\text { Saudi } \\
\text { Arabia }\end{array}$ & Kuwait & Qatar & Oman & UAE & Bahrain & & & \\
\hline 11 & $\begin{array}{c}\text { Hossein et al. } \\
\text { [27] }\end{array}$ & $\begin{array}{l}12 \text { OPEC countries } \\
\text { including Saudi Arabia, } \\
\text { Kuwait, Qatar and UAE }\end{array}$ & 1980-2008 & 4 & $\sqrt{ }$ & $\sqrt{ }$ & $\sqrt{ }$ & & $\sqrt{ }$ & & $\sqrt{ }$ & & \\
\hline 12 & Sweidan [14] & UAE & 1973-2008 & 1 & & & & & $\sqrt{ }$ & & $\sqrt{ }$ & & \\
\hline 13 & $\begin{array}{l}\text { Narayan and } \\
\text { Popp [28] }\end{array}$ & $\begin{array}{l}93 \text { countries including all } \\
\text { GCC countries }\end{array}$ & 1980-2006 & 6 & $\sqrt{ }$ & $\sqrt{ }$ & $\sqrt{ }$ & $\sqrt{ }$ & $\sqrt{ }$ & $\sqrt{ }$ & & $\sqrt{ }$ & \\
\hline 14 & $\begin{array}{l}\text { AlKhathlan } \\
\text { and Javid } \\
\text { [17] }\end{array}$ & Saudi Arabia & 1980-2011 & 4 & $\sqrt{ }$ & & & & & & $\sqrt{ }$ & & $\begin{array}{l}4 \text { models: } \\
\text { aggregate, oil, } \\
\text { gas and } \\
\text { electricity }\end{array}$ \\
\hline 15 & $\begin{array}{c}\text { Al-mulali } \\
\text { and Lee [29] }\end{array}$ & GCC countries & 1980-2009 & 6 & $\sqrt{ }$ & $\sqrt{ }$ & $\sqrt{ }$ & $\sqrt{ }$ & $\sqrt{ }$ & $\sqrt{ }$ & & $\sqrt{ }$ & \\
\hline 16 & $\begin{array}{l}\text { Al-mulali } \\
\text { and Tang } \\
{[30]}\end{array}$ & GCC countries & 1980-2010 & 6 & $\sqrt{ }$ & $\sqrt{ }$ & $\sqrt{ }$ & $\sqrt{ }$ & $\sqrt{ }$ & $\sqrt{ }$ & & $\sqrt{ }$ & \\
\hline 17 & Ozcan [31] & $\begin{array}{c}12 \text { Middle Eastern (ME) } \\
\text { countries including Saudi } \\
\text { Arabia, Bahrain, UAE and } \\
\text { Oman }\end{array}$ & 1990-2008 & 4 & $\sqrt{ }$ & & & $\sqrt{ }$ & $\sqrt{ }$ & $\sqrt{ }$ & & $\sqrt{ }$ & \\
\hline 18 & $\begin{array}{l}\text { Damette and } \\
\text { Seghir [32] }\end{array}$ & $\begin{array}{l}12 \text { oil-exporting countries } \\
\text { including Saudi Arabia and } \\
\text { UAE }\end{array}$ & 1990-2010 & 2 & $\sqrt{ }$ & & & & $\sqrt{ }$ & & & $\sqrt{ }$ & \\
\hline 19 & Omri [18] & $\begin{array}{c}14 \text { MENA countries } \\
\text { including } 6 \text { GCC countries }\end{array}$ & 1990-2011 & 12 & $\sqrt{ }$ & $\sqrt{ }$ & $\sqrt{ }$ & $\sqrt{ }$ & $\sqrt{ }$ & $\sqrt{ }$ & $\sqrt{ }$ & $\sqrt{ }$ & \\
\hline 20 & $\begin{array}{l}\text { Shahbaz } \\
\text { et al. [33] }\end{array}$ & UAE & 1975-2011 & 1 & & & & & $\sqrt{ }$ & & $\sqrt{ }$ & & \\
\hline 21 & $\begin{array}{l}\text { Salahuddin } \\
\text { and Gow } \\
\text { [34] }\end{array}$ & GCC countries & 1980-2012 & 6 & $\sqrt{ }$ & $\sqrt{ }$ & $\sqrt{ }$ & $\sqrt{ }$ & $\sqrt{ }$ & $\sqrt{ }$ & & $\sqrt{ }$ & \\
\hline 22 & $\begin{array}{c}\text { Al-Mulali } \\
\text { and Ozturk } \\
{[35]}\end{array}$ & GCC countries & 1980-2012 & 6 & $\sqrt{ }$ & $\sqrt{ }$ & $\sqrt{ }$ & $\sqrt{ }$ & $\sqrt{ }$ & $\sqrt{ }$ & $\sqrt{ }$ & & \\
\hline
\end{tabular}


Table 2. Cont

\begin{tabular}{|c|c|c|c|c|c|c|c|c|c|c|c|c|c|}
\hline \multirow[b]{2}{*}{ No } & \multirow[b]{2}{*}{ Study } & \multirow[b]{2}{*}{ Countries } & \multirow[b]{2}{*}{ Period } & \multirow{2}{*}{$\begin{array}{c}\text { No. of } \\
\text { Observations }\end{array}$} & \multicolumn{6}{|c|}{ One or More Countries } & \multirow{2}{*}{$\begin{array}{c}\text { Analyzed } \\
\text { Individually }\end{array}$} & \multirow{2}{*}{$\begin{array}{l}\text { Analyzed as } \\
\text { a Group }\end{array}$} & \multirow[b]{2}{*}{ Not } \\
\hline & & & & & $\begin{array}{c}\text { Saudi } \\
\text { Arabia }\end{array}$ & Kuwait & Qatar & Oman & UAE & Bahrain & & & \\
\hline 23 & Jalil [36] & $\begin{array}{l}29 \text { net energy-importing } \\
\text { countries and } 19 \text { net } \\
\text { energy-exporting countries } \\
\text { including UAE }\end{array}$ & 1970-2012 & 1 & & & & & $\sqrt{ }$ & & & $\sqrt{ }$ & \\
\hline 24 & $\begin{array}{l}\text { Mohammadi } \\
\text { and } \\
\text { Parvaresh } \\
\text { [37] }\end{array}$ & $\begin{array}{l}14 \text { oil-exporting countries } \\
\text { including Saudi Arabia, } \\
\text { Oman and Bahrain }\end{array}$ & 1980-2007 & 3 & $\sqrt{ }$ & & & $\sqrt{ }$ & & $\sqrt{ }$ & & $\sqrt{ }$ & \\
\hline 25 & $\begin{array}{c}\text { Sbia, } \\
\text { Shahbaz and } \\
\text { Hamdi [38] }\end{array}$ & UAE & $1975-2011$ & 1 & & & & & $\sqrt{ }$ & & $\sqrt{ }$ & & \\
\hline 26 & $\begin{array}{c}\text { Hamdi, Sbia } \\
\text { and Shahbaz } \\
\text { [39] }\end{array}$ & Bahrain & $1980-2010$ & 1 & & & & & & $\sqrt{ }$ & $\sqrt{ }$ & & \\
\hline 27 & $\begin{array}{l}\text { Salahuddin, } \\
\text { Gow and } \\
\text { Ozturk [40] }\end{array}$ & GCC countries & 1980-2012 & 6 & $\sqrt{ }$ & $\sqrt{ }$ & $\sqrt{ }$ & $\sqrt{ }$ & $\sqrt{ }$ & $\sqrt{ }$ & & $\sqrt{ }$ & \\
\hline 28 & $\begin{array}{l}\text { Karanfil and } \\
\text { Li [41] }\end{array}$ & $\begin{array}{c}160 \text { countries including } 6 \\
\text { GCC countries }\end{array}$ & 1980-2010 & 6 & $\sqrt{ }$ & $\sqrt{ }$ & $\sqrt{ }$ & $\sqrt{ }$ & $\sqrt{ }$ & $\sqrt{ }$ & & $\sqrt{ }$ & \\
\hline 29 & $\begin{array}{l}\text { Alshehry } \\
\text { and } \\
\text { Belloumi } \\
\text { [42] }\end{array}$ & Saudi Arabia & 1971-2010 & 1 & $\sqrt{ }$ & & & & & & $\sqrt{ }$ & & \\
\hline 30 & $\begin{array}{c}\text { Al-Mulali } \\
\text { and Ozturk } \\
{[43]}\end{array}$ & $\begin{array}{l}14 \text { MENA countries } \\
\text { including Saudi Arabia, } \\
\text { Kuwait, Oman and UAE }\end{array}$ & 1996-2012 & 4 & $\sqrt{ }$ & $\sqrt{ }$ & & $\sqrt{ }$ & $\sqrt{ }$ & & & $\sqrt{ }$ & \\
\hline 31 & $\begin{array}{l}\text { Iriani and } \\
\text { Trabelsi [44] }\end{array}$ & GCC countries & 1980-2011 & 6 & $\sqrt{ }$ & $\sqrt{ }$ & $\sqrt{ }$ & $\sqrt{ }$ & $\sqrt{ }$ & $\sqrt{ }$ & $\sqrt{ }$ & & \\
\hline 32 & $\begin{array}{l}\text { Kayikci and } \\
\text { Bildirici [45] }\end{array}$ & $\begin{array}{l}12 \text { ME countries including } \\
\text { Saudi Arabia, Bahrain, } \\
\text { Kuwait and Oman }\end{array}$ & 1972-2011 & 4 & $\sqrt{ }$ & $\sqrt{ }$ & & $\sqrt{ }$ & & $\sqrt{ }$ & $\sqrt{ }$ & & \\
\hline
\end{tabular}


Table 2. Cont

\begin{tabular}{|c|c|c|c|c|c|c|c|c|c|c|c|c|c|}
\hline \multirow[b]{2}{*}{ No } & \multirow[b]{2}{*}{ Study } & \multirow[b]{2}{*}{ Countries } & \multirow[b]{2}{*}{ Period } & \multirow[b]{2}{*}{$\begin{array}{c}\text { No. of } \\
\text { Observations }\end{array}$} & \multicolumn{6}{|c|}{ One or More Countries } & \multirow{2}{*}{$\begin{array}{l}\text { Analyzed } \\
\text { Individually }\end{array}$} & \multirow{2}{*}{$\begin{array}{l}\text { Analyzed as } \\
\text { a Group }\end{array}$} & \multirow[b]{2}{*}{ Note } \\
\hline & & & & & $\begin{array}{c}\text { Saudi } \\
\text { Arabia }\end{array}$ & Kuwait & Qatar & Oman & UAE & Bahrain & & & \\
\hline 33 & $\begin{array}{c}\text { Belloumi } \\
\text { and } \\
\text { Alshehry } \\
{[46]}\end{array}$ & Saudi Arabia & 1971-2012 & 1 & $\sqrt{ }$ & & & & & & $\sqrt{ }$ & & \\
\hline 34 & $\begin{array}{c}\text { Ozturk and } \\
\text { Al-Mulali } \\
\text { [47] }\end{array}$ & GCC countries & 1980-2012 & 6 & $\sqrt{ }$ & $\sqrt{ }$ & $\sqrt{ }$ & $\sqrt{ }$ & $\sqrt{ }$ & $\sqrt{ }$ & & $\sqrt{ }$ & \\
\hline 35 & $\begin{array}{l}\text { Magazzino } \\
{[48]}\end{array}$ & GCC countries & 1960-2013 & 6 & $\sqrt{ }$ & $\sqrt{ }$ & $\sqrt{ }$ & $\sqrt{ }$ & $\sqrt{ }$ & $\sqrt{ }$ & $\sqrt{ }$ & & \\
\hline 36 & $\begin{array}{l}\text { Ahmed and } \\
\text { Azam [49] }\end{array}$ & $\begin{array}{l}119 \text { countries including } \\
\text { Saudi Arabia, Bahrain, } \\
\text { Oman and UAE }\end{array}$ & $\begin{array}{l}\text { Different } \\
\text { Time } \\
\text { Spans }\end{array}$ & 4 & $\sqrt{ }$ & & & $\sqrt{ }$ & $\sqrt{ }$ & $\sqrt{ }$ & $\sqrt{ }$ & & \\
\hline 37 & $\begin{array}{l}\text { Magazzino } \\
{[50]}\end{array}$ & $\begin{array}{c}10 \text { MENA countries } \\
\text { including } 6 \text { GCC countries }\end{array}$ & 1971-2006 & 6 & $\sqrt{ }$ & $\sqrt{ }$ & $\sqrt{ }$ & $\sqrt{ }$ & $\sqrt{ }$ & $\sqrt{ }$ & & $\sqrt{ }$ & \\
\hline 38 & $\begin{array}{l}\text { Osman et al. } \\
{[12]}\end{array}$ & GCC countries & 1975-2012 & 6 & $\sqrt{ }$ & $\sqrt{ }$ & $\sqrt{ }$ & $\sqrt{ }$ & $\sqrt{ }$ & $\sqrt{ }$ & & $\sqrt{ }$ & \\
\hline 39 & $\begin{array}{l}\text { Charfeddine } \\
\text { and Khediri } \\
\text { [51] }\end{array}$ & UAE & 1975-2011 & 1 & & & & & $\sqrt{ }$ & & $\sqrt{ }$ & & \\
\hline 40 & $\begin{array}{l}\text { Solarin and } \\
\text { Ozturk [52] }\end{array}$ & $\begin{array}{l}12 \text { OPEC countries } \\
\text { including Saudi Arabia, } \\
\text { Kuwait, Qatar and UAE }\end{array}$ & 1980-2012 & 8 & $\sqrt{ }$ & $\sqrt{ }$ & $\sqrt{ }$ & & $\sqrt{ }$ & & $\sqrt{ }$ & $\sqrt{ }$ & \\
\hline 41 & Ozturk [53] & $\begin{array}{l}11 \text { MENA countries } \\
\text { including Saudi Arabia, } \\
\text { Bahrain, Oman and UAE }\end{array}$ & 1971-2011 & 4 & $\sqrt{ }$ & & & $\sqrt{ }$ & $\sqrt{ }$ & $\sqrt{ }$ & $\sqrt{ }$ & & \\
\hline 42 & $\begin{array}{l}\text { Hasanov } \\
\text { et al. [54] }\end{array}$ & $\begin{array}{l}10 \text { oil-exporting developing } \\
\text { Eurasian countries } \\
\text { including all GCC countries }\end{array}$ & 1997-2014 & 12 & $\sqrt{ }$ & $\sqrt{ }$ & $\sqrt{ }$ & $\sqrt{ }$ & $\sqrt{ }$ & $\sqrt{ }$ & & $\sqrt{ }$ & $\begin{array}{l}2 \text { models: } \\
\text { residential } \\
\text { electricity and } \\
\text { total energy }\end{array}$ \\
\hline
\end{tabular}


Table 2. Cont

\begin{tabular}{|c|c|c|c|c|c|c|c|c|c|c|c|c|c|}
\hline \multirow[b]{2}{*}{ No } & \multirow[b]{2}{*}{ Study } & \multirow[b]{2}{*}{ Countries } & \multirow[b]{2}{*}{ Period } & \multirow[b]{2}{*}{$\begin{array}{c}\text { No. of } \\
\text { Observations }\end{array}$} & \multicolumn{6}{|c|}{ One or More Countries } & \multirow{2}{*}{$\begin{array}{l}\text { Analyzed } \\
\text { Individually }\end{array}$} & \multirow{2}{*}{$\begin{array}{l}\text { Analyzed as } \\
\text { a Group }\end{array}$} & \multirow[b]{2}{*}{ Note } \\
\hline & & & & & $\begin{array}{l}\text { Saudi } \\
\text { Arabia }\end{array}$ & Kuwait & Qatar & Oman & UAE & Bahrain & & & \\
\hline 43 & $\begin{array}{l}\text { Antonakakis } \\
\text { et al. [55] }\end{array}$ & $\begin{array}{l}106 \text { countries including all } \\
\text { GCC countries }\end{array}$ & 1971-2011 & 36 & $\sqrt{ }$ & $\sqrt{ }$ & $\sqrt{ }$ & $\sqrt{ }$ & $\sqrt{ }$ & $\sqrt{ }$ & & $\sqrt{ }$ & $\begin{array}{l}6 \text { models: total } \\
\text { energy, } \\
\text { electricity, oil, } \\
\text { renewable } \\
\text { energy, natural } \\
\text { gas and coal }\end{array}$ \\
\hline 44 & $\begin{array}{c}\text { Mahalik et al. } \\
\text { [56] }\end{array}$ & Saudi Arabia & 1971-2011 & 1 & $\sqrt{ }$ & & & & & & $\sqrt{ }$ & & \\
\hline 45 & $\begin{array}{l}\text { Charfeddine } \\
\text { and Mrabet } \\
\text { [57] }\end{array}$ & $\begin{array}{l}15 \text { MENA countries } \\
\text { including Saudi Arabia, } \\
\text { Qatar, Oman and Kuwait }\end{array}$ & 1975-2007 & 4 & $\sqrt{ }$ & $\sqrt{ }$ & $\sqrt{ }$ & $\sqrt{ }$ & & & & $\sqrt{ }$ & \\
\hline 46 & $\begin{array}{c}\text { Charfeddine } \\
\text { [58] }\end{array}$ & Qatar & 1970-2016 & 2 & & & $\sqrt{ }$ & & & & $\sqrt{ }$ & & $\begin{array}{c}2 \text { models: } \\
\text { ecological } \\
\text { footprint and } \\
\mathrm{CO}_{2}\end{array}$ \\
\hline 47 & $\begin{array}{l}\text { Bekhet et al. } \\
\text { [59] }\end{array}$ & GCC countries & 1980-2011 & 6 & $\sqrt{ }$ & $\sqrt{ }$ & $\sqrt{ }$ & $\sqrt{ }$ & $\sqrt{ }$ & $\sqrt{ }$ & $\sqrt{ }$ & & \\
\hline 48 & $\begin{array}{l}\text { Charfeddine } \\
\text { et al. [60] }\end{array}$ & Qatar & 1970-2014 & 1 & & & $\sqrt{ }$ & & & & $\sqrt{ }$ & & \\
\hline 49 & $\begin{array}{l}\text { Salahuddin } \\
\text { et al. [61] }\end{array}$ & Kuwait & 1980-2013 & 1 & & $\sqrt{ }$ & & & & & $\sqrt{ }$ & & \\
\hline 50 & Xu et al. [62] & Saudi Arabia & 2071-2016 & 1 & $\sqrt{ }$ & & & & & & $\sqrt{ }$ & & \\
\hline 51 & $\begin{array}{l}\text { Al-Mulali } \\
\text { and Sab [63] }\end{array}$ & $\begin{array}{l}12 \text { MENA countries } \\
\text { including all GCC countries }\end{array}$ & 1990-2008 & 6 & $\sqrt{ }$ & $\sqrt{ }$ & $\sqrt{ }$ & $\sqrt{ }$ & $\sqrt{ }$ & $\sqrt{ }$ & & $\sqrt{ }$ & \\
\hline 52 & $\begin{array}{l}\text { Al-Mulali } \\
\text { and Sab [64] }\end{array}$ & UAE & 1980-2008 & 1 & & & & & $\sqrt{ }$ & & $\sqrt{ }$ & & \\
\hline 53 & $\begin{array}{l}\text { Sekrafi and } \\
\text { Sghaier [65] }\end{array}$ & $\begin{array}{c}13 \text { MENA countries } \\
\text { including Saudi Arabia, } \\
\text { Qatar, Oman, Bahrain and } \\
\text { UAE }\end{array}$ & 1984-2012 & 5 & $\sqrt{ }$ & & $\sqrt{ }$ & $\sqrt{ }$ & $\sqrt{ }$ & $\sqrt{ }$ & & $\sqrt{ }$ & \\
\hline 54 & $\begin{array}{l}\text { Wang et al. } \\
\text { [66] }\end{array}$ & $\begin{array}{l}170 \text { countries including } \\
\text { Saudi Arabia, Bahrain, } \\
\text { Oman, Kuwait and UAE }\end{array}$ & 1980-2011 & 5 & $\sqrt{ }$ & $\sqrt{ }$ & & $\sqrt{ }$ & $\sqrt{ }$ & $\sqrt{ }$ & & $\sqrt{ }$ & \\
\hline
\end{tabular}


Table 2. Cont

\begin{tabular}{|c|c|c|c|c|c|c|c|c|c|c|c|c|c|}
\hline \multirow[b]{2}{*}{ No } & \multirow[b]{2}{*}{ Study } & \multirow[b]{2}{*}{ Countries } & \multirow[b]{2}{*}{ Period } & \multirow[b]{2}{*}{$\begin{array}{c}\text { No. of } \\
\text { Observations }\end{array}$} & \multicolumn{6}{|c|}{ One or More Countries } & \multirow[b]{2}{*}{$\begin{array}{c}\text { Analyzed } \\
\text { Individually }\end{array}$} & \multirow[b]{2}{*}{$\begin{array}{l}\text { Analyzed as } \\
\text { a Group }\end{array}$} & \multirow[b]{2}{*}{ Note } \\
\hline & & & & & $\begin{array}{c}\text { Saudi } \\
\text { Arabia }\end{array}$ & Kuwait & Qatar & Oman & UAE & Bahrain & & & \\
\hline 55 & $\begin{array}{l}\text { Al-Mulali } \\
\text { et al. [67] }\end{array}$ & GCC countries & 1980-2014 & 6 & $\sqrt{ }$ & $\sqrt{ }$ & $\sqrt{ }$ & $\sqrt{ }$ & $\sqrt{ }$ & $\sqrt{ }$ & & $\sqrt{ }$ & \\
\hline 56 & $\begin{array}{l}\text { Gorus and } \\
\text { Aydin [68] }\end{array}$ & $\begin{array}{l}8 \text { MENA countries } \\
\text { including Saudi Arabia, } \\
\text { UAE and Oman }\end{array}$ & 1975-2014 & 3 & $\sqrt{ }$ & & & $\sqrt{ }$ & $\sqrt{ }$ & & $\sqrt{ }$ & & \\
\hline 57 & $\begin{array}{c}\text { Charfeddine } \\
\text { and Kahia } \\
\text { [69] }\end{array}$ & $\begin{array}{l}24 \text { MENA countries } \\
\text { including all GCC countries }\end{array}$ & 1980-2015 & 6 & $\sqrt{ }$ & $\sqrt{ }$ & $\sqrt{ }$ & $\sqrt{ }$ & $\sqrt{ }$ & $\sqrt{ }$ & & $\sqrt{ }$ & \\
\hline 58 & $\begin{array}{c}\text { Akadiri et al. } \\
\text { [70] }\end{array}$ & Saudi Arabia & 1968-2016 & 1 & $\sqrt{ }$ & & & & & & $\sqrt{ }$ & & \\
\hline 59 & $\begin{array}{l}\text { Alsaedi and } \\
\text { Tularam [71] }\end{array}$ & Saudi Arabia & 1990-2015 & 1 & $\sqrt{ }$ & & & & & & $\sqrt{ }$ & & \\
\hline
\end{tabular}


To understand the relationship between energy consumption and economic growth from various perspectives, the paper will classify the studies using the following five dimensions:

1. Time span: in order to study the energy-growth nexus, researchers used data spanning over many years. Some studies used short time spans such as 20 years while others used long ones such as 40 years.

2. Variables used: the main focus of our review paper was to review the studies investigating the relationship between energy consumption and economic growth. Some studies used energy consumption and economic growth as the only two variables. However, some studies used additional variables such as imports and exports, $\mathrm{CO}_{2}$ emission, urbanization and foreign direct investment. We reported these additional variables to highlight the full list of the variables used in these studies and to help future researchers interested in this topic of the GCC countries context to get an idea of the set of variables to be included in their research.

3. Level of analysis: some studies investigated the relationship on an individual country level while others analyzed the relationship on a panel of a group of countries. For example, Sweidan [14] investigated the energy-growth relationship for the UAE. On the other hand, Al-Iriani [15] explored this relationship for all six GCC countries.

4. Econometric methodology: Charfeddine et al. [60] classified the econometric methodology used to investigate the causal relationship between energy consumption and economic growth into five categories:
a. Engle-Granger and Johansen-Juselius approaches [27].
b. Autoregressive distributed lag (ARDL) bounds test [16].
c. Gregory and Hansen, Hatemi-J and Markov switching approach [58].
d. Pedroni panel cointegration and Westerlund panel cointegration and other panel methods $[15,22,28]$.
e. Other methods: any method that was not classified under one of the four categories was categorized as other methods. Examples of such methods are the time domain analysis and frequency domain analysis methods [68].

5. Hypothesis: as discussed earlier, there were four hypotheses which could be tested in the energy-economic nexus. These four hypotheses are:
a. Growth
b. Conservation
c. Feedback
d. Neutrality

In the two sub-sections below, we will chronologically list all the articles on the energy-growth nexus and discuss the authors, time span, methodology used and empirical results. The first sub-section will discuss the individual country-specific studies while the second sub-section will discuss the multi-country studies.

\subsection{Individual Country Specific Studies}

\subsubsection{Bahrain}

Hamdi et al. [39] explored the relationship between the GDP, electricity consumption, foreign direct investment and capital in Bahrain. They analyzed the data over the period 1980-2010 using the ARDL technique. The results showed that there was a bi-directional relationship between electricity consumption and economic growth supporting the feedback hypothesis. Table 3 shows the energy-growth articles related to Bahrain. 


\subsubsection{Kuwait}

Salahuddin et al. [61] examined the relationship between GDP, electricity consumption, $\mathrm{CO}_{2}$, foreign direct investment and financial development in Kuwait. They also used the ARDL technique to analyze the data over the period 1980-2013. They found there was a bidirectional relationship between electricity consumption and economic growth supporting the feedback hypothesis. Table 4 shows the energy-growth articles related to Kuwait.

\subsubsection{Saudi Arabia}

Alkhathlan and Javid [17] examined the relationship between energy consumption, carbon emission and economic growth in Saudi Arabia over the period 1980-2001 using the ARDL technique. They analyzed four models. The first one was the aggregate one in which the total energy consumption was used. The remaining three models were disaggregated in which oil consumption, gas and electricity consumption were evaluated separately. For the aggregated model, they found no relation between total energy and economic growth supporting the neutrality hypothesis. For the oil consumption model, there was a causal relationship from oil consumption to GDP supporting the growth hypothesis. On the other hand, for the gas model there was unidirectional causality running from GDP to gas consumption supporting the conservation hypothesis. Finally, for the electricity model, there was no relationship between electricity consumption and economic growth supporting the neutrality hypothesis. Alshehry and Belloumi [42] investigated the relationship between GDP, energy consumption, energy prices and $\mathrm{CO}_{2}$ in Saudi Arabia. They analyzed the data for the period 1971-2010 using the Johansen multivariate cointegration technique. The results showed that there was a uni-directional causality from energy consumption to economic growth supporting the growth hypothesis. Belloumi and Alshehry [46] investigated the relationship between energy consumption and economic growth over the period 1971-2012 using the ARDL technique. The results supported the growth hypothesis. Mahalik et al. [56] explored the relationship between GDP, energy consumption, financial development, capital and urbanization in Saudi Arabia over the period 1971-2011. They used both the Bayer-Hanck combined cointegration and the ADRL techniques and found that there was no relationship between GDP and energy consumption, supporting the neutrality hypothesis. $\mathrm{Xu}$ et al. [62] examined the relationship between GDP, electricity consumption, $\mathrm{CO}_{2}$, globalization, urbanization and financial development in Saudi Arabia. They used the ARDL technique to analyze the data over the period 1971-2016. The results supported the growth hypothesis. Akadiri et al. [70] examined the relationship between GDP, natural gas and total trade for Saudi Arabia over the period 1968-2016. They used the ARDL technique and concluded that there was uni-directional causality running from natural gas consumption to GDP, supporting the growth hypothesis. Alsaedi and Tularam [71] investigated the relationship between GDP, electricity consumption and $\mathrm{CO}_{2}$ in Saudi Arabia. They used the Johansen-Juselius approach to analyze the data over the period 1990-2015. The results supported the conservation hypothesis. Table 5 shows the energy-growth articles related to Saudi Arabia.

\subsubsection{Qatar}

Charfeddine [58] investigated the impact of energy consumption and economic growth on the ecological footprint in the first model and the impact of energy consumption and economic growth on $\mathrm{CO}_{2}$ emission in the second model in Qatar. He used the Gregory and Hansen and Hatemi-J techniques to find the relationship over the period 1970-2016. The results showed that there was a bi-directional relationship between electricity and GDP, supporting the feedback hypothesis for the ecological model. On the other hand, there was a uni-directional causality from electricity to GDP, supporting the growth hypothesis for the $\mathrm{CO}_{2}$ model. Charfeddine et al. [60] examined the relationship between GDP, energy consumption, electricity consumption, real capital per capita, labor force, urbanization and trade openness. They used the ARDL technique to analyze the data over the period 1970-2014 and found that the growth hypothesis was supported. Table 6 shows the energy-growth articles related to Qatar. 


\subsubsection{UAE}

Sweidan [14] used the ARDL technique to investigate the relationship between energy consumption and economic growth in the UAE over the period 1973-2008. The results showed that there was a bidirectional relationship between energy consumption and economic growth supporting the feedback hypothesis. Shahbaz et al. [33] used the ARDL technique to explore the relationship between GDP, electricity consumption, $\mathrm{CO}_{2}$, export and urbanization in the UAE over the period 1975-2011. The results supported the feedback hypothesis in which there is a bi-directional relationship between electricity consumption and economic growth. Sbia et al. [38] investigated the relationship between GDP, energy consumption, foreign direct investment, natural gas consumption, trade openness and $\mathrm{CO}_{2}$ in the UAE in the period 1975-2011. They used the ARDL technique to analyze the data. The results showed that there was a bi-directional relationship between energy consumption and economic growth supporting the feedback hypothesis. Charfeddine and Khediri [51] examined the relationship between GDP, electricity consumption, $\mathrm{CO}_{2}$, financial development, urbanization and trade openness in the UAE. They used the Gregory and Hansen and Hatemi-J techniques to analyze the data over the period 1975-2011. The results showed that there was a bi-directional relationship between electricity consumption and economic growth, supporting the feedback hypothesis. Al-Mulali and Sab [63] investigated the impact of energy consumption and $\mathrm{CO}_{2}$ emission on economic growth and financial development in the UAE. They used the Johansen-Juselius technique to analyze the data over the period 1980-2008. The results supported the growth hypothesis in which energy consumption causes economic growth. Table 7 shows the energy-growth articles related to the UAE. 
Table 3. Energy-growth articles related to Bahrain.

\begin{tabular}{|c|c|c|c|c|c|c|c|c|c|c|c|c|c|}
\hline \multirow[b]{2}{*}{ No. } & \multirow[b]{2}{*}{ Study } & \multirow[b]{2}{*}{ Period } & \multirow[b]{2}{*}{ Variables } & \multicolumn{5}{|c|}{ Econometric Methodology } & \multicolumn{4}{|c|}{ Hypothesis } & \multirow[b]{2}{*}{ Note } \\
\hline & & & & $\begin{array}{l}\text { Engle-Granger } \\
\text { and Johansen- } \\
\text { Juselius }\end{array}$ & $\begin{array}{l}\text { ARDL } \\
\text { Bounds } \\
\text { Test }\end{array}$ & $\begin{array}{l}\text { Gregory and } \\
\text { Hansen, } \\
\text { Hatemi-J } \\
\text { and Markov } \\
\text { Switching } \\
\text { Approach }\end{array}$ & $\begin{array}{c}\text { Pedroni Panel } \\
\text { Cointegration } \\
\text { and Westerlund } \\
\text { Panel } \\
\text { Cointegration } \\
\text { and Other } \\
\text { Panel Methods }\end{array}$ & $\begin{array}{c}\text { Other } \\
\text { Methods }\end{array}$ & Growth & Conservation & Feedback & Neutral & \\
\hline 1 & $\begin{array}{c}\text { Hamdi, } \\
\text { Sbia and } \\
\text { Shahbaz } \\
{[39]}\end{array}$ & 1980-2010 & $\begin{array}{c}\text { GDP, } \\
\text { electricity } \\
\text { consumption, } \\
\text { foreign direct } \\
\text { investment } \\
\text { and capital }\end{array}$ & & $\sqrt{ }$ & & & & & & $\sqrt{ }$ & & \\
\hline
\end{tabular}

Table 4. Energy-growth articles related to Kuwait.

\begin{tabular}{|c|c|c|c|c|c|c|c|c|c|c|c|c|c|}
\hline \multirow[b]{2}{*}{ No. } & \multirow[b]{2}{*}{ Study } & \multirow[b]{2}{*}{ Period } & \multirow[b]{2}{*}{ Variables } & \multicolumn{5}{|c|}{ Econometric Methodology } & \multicolumn{4}{|c|}{ Hypothesis } & \multirow[b]{2}{*}{ Note } \\
\hline & & & & $\begin{array}{l}\text { Engle-Granger } \\
\quad \text { and } \\
\text { Johansen-Juselius }\end{array}$ & $\begin{array}{l}\text { ARDL } \\
\text { Bounds } \\
\text { Test }\end{array}$ & $\begin{array}{c}\text { Gregory and } \\
\text { Hansen, } \\
\text { Hatemi-J } \\
\text { and Markov } \\
\text { Switching } \\
\text { Approach }\end{array}$ & $\begin{array}{l}\text { Pedroni Panel } \\
\text { Cointegration } \\
\text { and Westerlund } \\
\text { Panel } \\
\text { Cointegration } \\
\text { and Other } \\
\text { Panel Methods }\end{array}$ & $\begin{array}{c}\text { Other } \\
\text { Methods }\end{array}$ & Growth & Conservation & Feedback & Neutral & \\
\hline 1 & $\begin{array}{l}\text { Salahuddin } \\
\text { et al. [61] }\end{array}$ & 1980-2013 & $\begin{array}{c}\text { GDP, } \\
\text { electricity } \\
\text { consumption, } \\
\mathrm{CO}_{2} \text {, foreign } \\
\text { direct } \\
\text { investment, } \\
\text { financial } \\
\text { development }\end{array}$ & & $\sqrt{ }$ & & & & & & $\sqrt{ }$ & & \\
\hline
\end{tabular}


Table 5. Energy-growth articles related to Saudi Arabia.

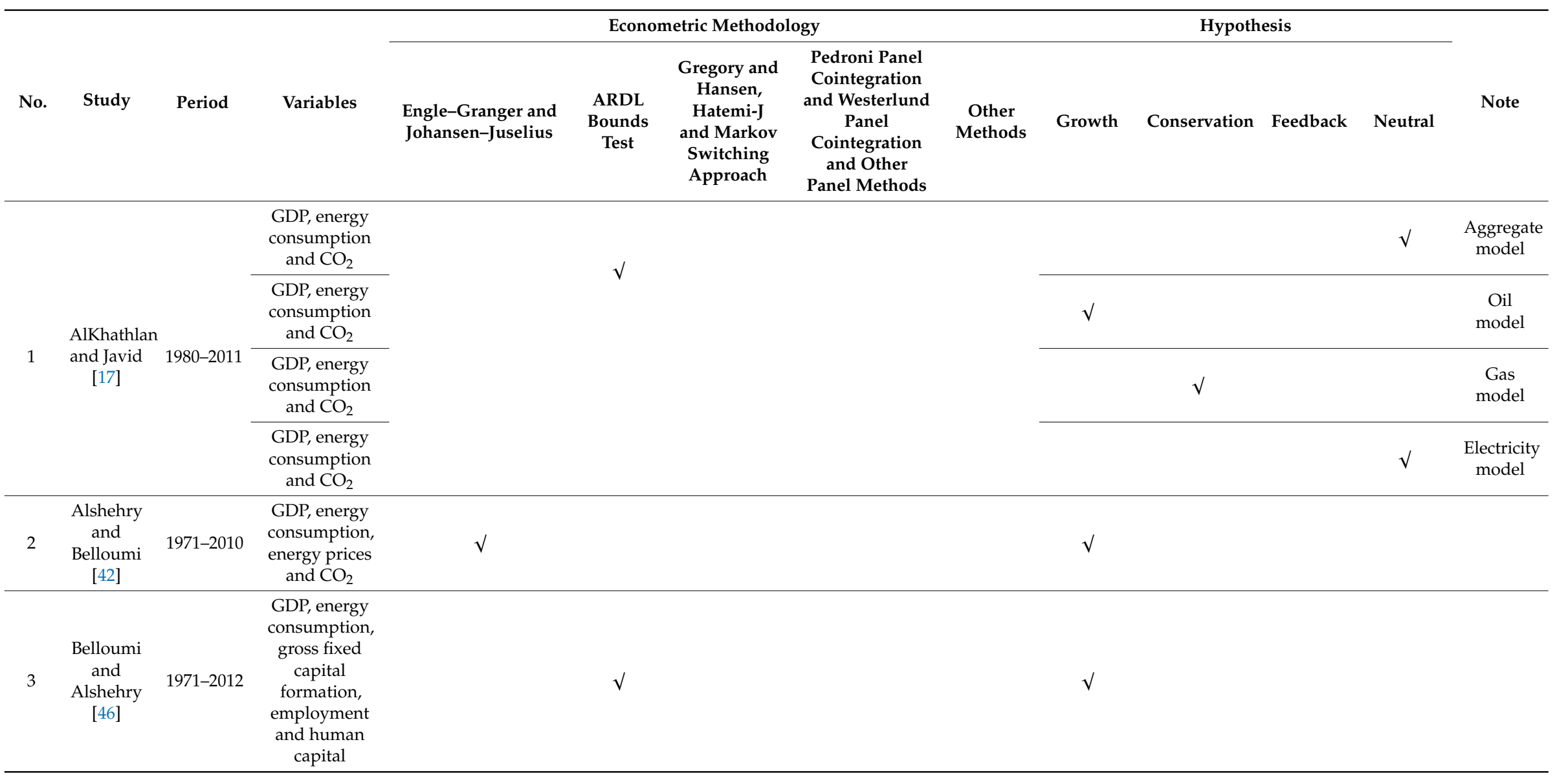


Table 5. Cont

\begin{tabular}{|c|c|c|c|c|c|c|c|c|c|c|c|c|c|}
\hline \multirow[b]{2}{*}{ No. } & \multirow[b]{2}{*}{ Study } & \multirow[b]{2}{*}{ Period } & \multirow[b]{2}{*}{ Variables } & \multicolumn{5}{|c|}{ Econometric Methodology } & \multicolumn{4}{|c|}{ Hypothesis } & \multirow[b]{2}{*}{ Note } \\
\hline & & & & $\begin{array}{l}\text { Engle-Granger and } \\
\text { Johansen-Juselius }\end{array}$ & $\begin{array}{l}\text { ARDL } \\
\text { Bounds } \\
\text { Test }\end{array}$ & $\begin{array}{l}\text { Gregory and } \\
\text { Hansen, } \\
\text { Hatemi-J } \\
\text { and Markov } \\
\text { Switching } \\
\text { Approach }\end{array}$ & $\begin{array}{c}\text { Pedroni Panel } \\
\text { Cointegration } \\
\text { and Westerlund } \\
\text { Panel } \\
\text { Cointegration } \\
\text { and Other } \\
\text { Panel Methods }\end{array}$ & $\begin{array}{c}\text { Other } \\
\text { Methods }\end{array}$ & Growth & Conservation & Feedback & Neutral & \\
\hline 4 & $\begin{array}{l}\text { Mahalik } \\
\text { et al. [56] }\end{array}$ & 1971-2011 & $\begin{array}{l}\text { GDP, energy } \\
\text { consumption, } \\
\text { financial } \\
\text { development, } \\
\text { capital and } \\
\text { urbanization }\end{array}$ & & $\sqrt{ }$ & & & $\sqrt{ }$ & & & & $\sqrt{ }$ & \\
\hline 5 & $\begin{array}{l}\text { Xu et al. } \\
\text { [62] }\end{array}$ & 1971-2016 & $\begin{array}{c}\text { GDP, } \\
\text { electricity } \\
\text { consumption, } \\
\mathrm{CO}_{2} \\
\text { globalization, } \\
\text { urbanization } \\
\text { and financial } \\
\text { development }\end{array}$ & & $\sqrt{ }$ & & & & $\sqrt{ }$ & & & & \\
\hline 6 & $\begin{array}{l}\text { Akadiri } \\
\text { et al. [70] }\end{array}$ & 1968-2016 & $\begin{array}{l}\text { GDP, natural } \\
\text { gas and total } \\
\text { trade }\end{array}$ & & $\sqrt{ }$ & & & & $\sqrt{ }$ & & & & \\
\hline 7 & $\begin{array}{c}\text { Alsaedi } \\
\text { and } \\
\text { Tularam } \\
\text { [71] }\end{array}$ & 1990-2015 & $\begin{array}{l}\text { GDP, energy } \\
\text { consumption } \\
\text { and } \mathrm{CO}_{2}\end{array}$ & $\sqrt{ }$ & & & & & & $\sqrt{ }$ & & & \\
\hline
\end{tabular}


Table 6. Energy-growth Articles Related to Qatar.

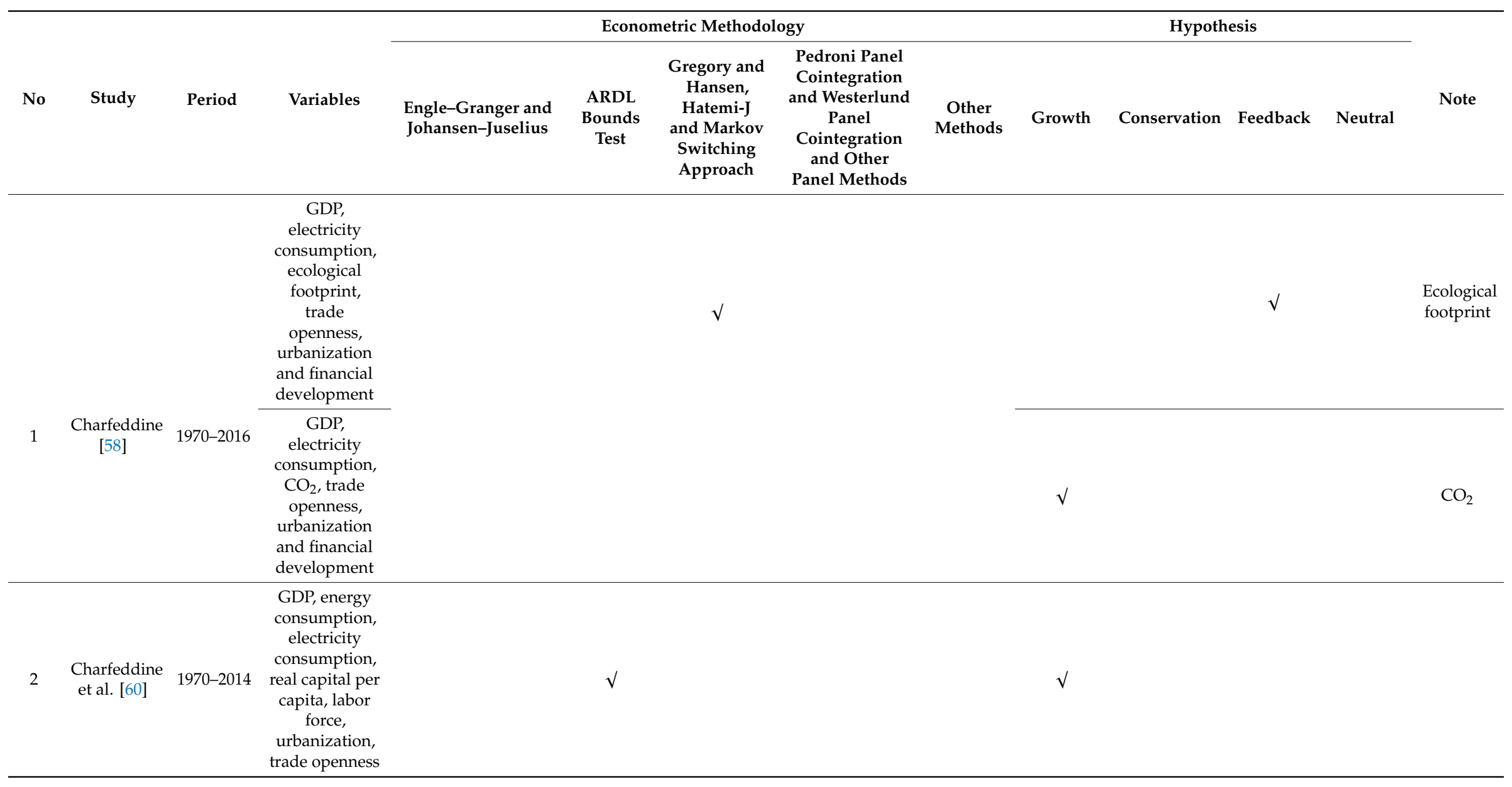


Table 7. Energy-growth articles related to UAE.

\begin{tabular}{|c|c|c|c|c|c|c|c|c|c|c|c|c|c|}
\hline \multirow[b]{2}{*}{ No } & \multirow[b]{2}{*}{ Study } & \multirow[b]{2}{*}{ Period } & \multirow[b]{2}{*}{ Variables } & \multicolumn{5}{|c|}{ Econometric Methodology } & \multicolumn{4}{|c|}{ Hypothesis } & \multirow[b]{2}{*}{ Note } \\
\hline & & & & $\begin{array}{l}\text { Engle-Granger } \\
\text { and } \\
\text { Johansen-Juselius }\end{array}$ & $\begin{array}{l}\text { ARDL } \\
\text { Bounds } \\
\text { Test }\end{array}$ & $\begin{array}{l}\text { Gregory and } \\
\text { Hansen, } \\
\text { Hatemi-J } \\
\text { and Markov } \\
\text { Switching } \\
\text { Approach }\end{array}$ & $\begin{array}{l}\text { Pedroni Panel } \\
\text { Cointegration } \\
\text { and Westerlund } \\
\text { Panel } \\
\text { Cointegration } \\
\text { and Other } \\
\text { Panel Methods }\end{array}$ & $\begin{array}{c}\text { Other } \\
\text { Methods }\end{array}$ & Growth & Conservation & Feedback & Neutral & \\
\hline 1 & $\begin{array}{c}\text { Sweidan } \\
{[14]}\end{array}$ & 1973-2008 & $\begin{array}{l}\text { GDP and } \\
\text { energy } \\
\text { consumption }\end{array}$ & & $\sqrt{ }$ & & & & & & $\sqrt{ }$ & & \\
\hline 2 & $\begin{array}{l}\text { Shahbaz } \\
\text { et al. [33] }\end{array}$ & 1975-2011 & $\begin{array}{l}\text { GDP, energy } \\
\text { consumption, } \\
\mathrm{CO}_{2} \text {, export } \\
\text { and } \\
\text { urbanization }\end{array}$ & & $\sqrt{ }$ & & & & & & $\sqrt{ }$ & & \\
\hline 3 & $\begin{array}{c}\text { Sbia, } \\
\text { Shahbaz } \\
\text { and Hamdi } \\
{[38]}\end{array}$ & 1975-2011 & $\begin{array}{l}\text { GDP, energy } \\
\text { consumption, } \\
\text { foreign direct } \\
\text { investment, } \\
\text { natural gas } \\
\text { consumption, } \\
\text { trade openness } \\
\text { and } \mathrm{CO}_{2} \\
\end{array}$ & & $\sqrt{ }$ & & & & & & $\sqrt{ }$ & & \\
\hline 4 & $\begin{array}{c}\text { Charfeddine } \\
\text { and } \\
\text { Khediri } \\
\text { [51] }\end{array}$ & 1975-2011 & $\begin{array}{l}\text { GDP, energy } \\
\text { consumption, } \\
\mathrm{CO}_{2} \text {, financial } \\
\text { development, } \\
\text { urbanization, } \\
\text { trade openness }\end{array}$ & & & $\sqrt{ }$ & & & & & $\sqrt{ }$ & & \\
\hline 5 & $\begin{array}{l}\text { Al-Mulali } \\
\text { and Sab } \\
\text { [64] }\end{array}$ & 1980-2008 & $\begin{array}{l}\text { GDP, energy } \\
\text { consumption, } \\
\mathrm{CO}_{2} \text { and } \\
\text { financial } \\
\text { development }\end{array}$ & $\sqrt{ }$ & & & & & $\sqrt{ }$ & & & & \\
\hline
\end{tabular}




\subsection{Multi-Country Studies}

Al-Iriani [15] published the first paper on the energy-growth nexus in the GCC countries context. He investigated the relationship between energy consumption and gross domestic product (GDP) for the six GCC states. He used the Pedroni panel cointegration technique to analyze the data covering the period 1971-2002. The results showed that GDP causes energy consumption, supporting the conservation hypothesis. Mehrara [19] examined the relationship between per capita energy consumption and per capita GDP in a panel of 11 oil-exporting countries. He included five GCC countries. These were Kuwait, Saudi Arabia, UAE, Bahrain and Oman. He analyzed the relationship using the Pedroni panel cointegration for the period 1971-2002. The results supported the conservation hypothesis that GDP causes energy consumption. Squalli [16] investigated the relationship between electricity consumption and economic growth for OPEC countries. He included four GCC countries in the analysis, namely Kuwait, Qatar, Saudi Arabia and the UAE. He used the ADRL technique and the Toda-Yamamoto technique to investigate the causality relationship for each country individually over the period 1980-2003. The results of the short-term analysis showed that there was a bi-directional relationship between electricity consumption and economic growth for Saudi Arabia and Qatar, supporting the feedback hypothesis. For Kuwait, the causality ran from economic growth to electricity consumption, supporting the conservation hypothesis. For the UAE, electricity consumption caused economic growth, which supported the growth hypothesis. Mahadevan and Asafu-Adjaye [20] analyzed the relationship between energy consumption and economic growth for 10 net energy-importing and 10 energy-exporting countries. Among the net energy-exporting countries, they selected Kuwait and Saudi Arabia for the analysis. In addition to energy consumption and economic growth, they added prices as a control variable. They used the Pedroni panel cointegration and the panel-based vector error correction model (VECM) techniques to determine the causality relationship over the period 1971-2002. For the net energy-exporting countries, the analysis showed a bi-directional relationship between energy consumption and economic growth supporting the feedback hypothesis. Mehrara, M. [21] examined the relationship between energy consumption and economic growth for three oil-exporting countries including Kuwait and Saudi Arabia. He used the data covering the period 1971-2002 and applied the Johansen test as well as the VECM and Toda-Yamamoto techniques to determine the causality relationship. The results for Saudi Arabia showed that the energy consumption caused economic growth, supporting the growth hypothesis while it was the opposite for Kuwait. For Kuwait, economic growth caused energy consumption, supporting the conservation hypothesis. Narayan and Smyth [22] analyzed the causality relationship between electricity consumption and economic growth taking exports as a control variable. The analysis was performed on six Middle Eastern countries including Kuwait, Oman and Saudi Arabia over the period 1974-2002. They performed the analysis using the Westerlund panel cointegration technique and found that for the short term, there was a unidirectional causality from electricity consumption to economic growth, supporting the growth hypothesis. Ozturk et al. [23] analyzed the causal relationship between energy consumption and economic growth for 51 countries over the period 1971-2005. They divided the countries into three categories: low-income group, lower middle-income group and upper middle-income group. They included Oman in the upper middle-income group. They used the Pedroni panel cointegration technique for the three groups. For the upper middle-income group, including Oman, the results supported the feedback hypothesis, in which there was a bidirectional relationship between energy consumption and economic growth. Al-Mulali [24] examined the relationship between oil consumption, $\mathrm{CO}_{2}$ emission and economic growth in Middle Eastern and North African (MENA) countries including all six GCC countries. He analyzed the data for the period 1980-2009 using the Pedroni, Kao and Fisher panel cointegration technique. The results showed that there was a bi-directional relationship between oil consumption and economic growth for these countries, supporting the feedback hypothesis. Sadorsky [25] used the Pedroni panel cointegration technique to examine the relationship between energy demand, energy price, income and trade openness among eight Middle Eastern countries including Bahrain, 
Oman, Qatar, Saudi Arabia and the UAE over the period 1980-2007. The results showed there was a bi-directional relationship between energy demand and income, supporting the feedback hypothesis. Ozturk and Acaravci [26] investigated the relationship between electricity consumption and GDP for 11 Middle Eastern countries including Oman, Saudi Araba and the UAE. They analyzed the data using the ARDL technique over the period 1971-2006. The UAE was removed from the analysis because the data violated the underlying assumptions of the ADRL approach. The results showed that for Oman there was a unidirectional causality running from GDP to electricity consumption in the short term, supporting the conservation hypothesis. On the other hand, the results showed no relationship between GDP and electricity consumption for Saudi Arabia in the short term supporting the neutrality hypothesis. Hossein et al. [27] examined the relationship between energy consumption, energy prices and economic growth for 12 OPEC countries including Kuwait, Qatar, Saudi Arabia and the UAE. They analyzed the data covering the period 1980-2008 using the Johansen-Juselius technique. The results showed that GDP caused energy consumption for Kuwait, Qatar, Saudi Arabia and the UAE in the short run, supporting the conservation hypothesis. Narayan and Popp [28] analyzed the data for 93 countries to examine the relationship between energy consumption and GDP over the period 1980-2006. They estimated the causality relationship for seven panels: Western Europe, Asia, Latin America, the Middle East including all six GCC countries, Africa and the six most industrialized countries (G6). They used the Kao panel and the Fisher panel techniques to analyze the data for the seven panels. For the Middle East, the results showed that there was no relationship between energy consumption and GDP, supporting the neutrality hypothesis. Al-Mulali and Lee [29] investigated the relationship between energy consumption, financial development, GDP, urbanization and total trade for the GCC countries. They used the Pedroni panel cointegration technique to analyze the data over the period 1980-2009. The results showed that there was a bi-directional relationship between energy consumption and economic growth, supporting the feedback hypothesis. Al-Mulali and Tang [30] investigated the relationship between $\mathrm{CO}_{2}$ emission, foreign direct investment, energy consumption and growth over the period 1980-2009. They employed the Pedroni panel cointegration technique and found that there was a bi-directional relationship between energy consumption and economic growth supporting the feedback hypothesis. Ozcan [31] investigated the relationship between carbon emission, energy consumption and economic growth in 12 Middle East countries including Bahrain, Oman, Saudi Arabia and the UAE. He used the Pedroni panel cointegration technique over the period 1990-2008 and found that there was a causality relationship running from economic growth to energy consumption, supporting the conservation hypothesis. Damette and Seghir [32] investigated the relationship between energy consumption and GDP for 12 oil-exporting countries including Saudi Arabia and UAE. They analyzed the data over the period 1990-2010 using both the Westerlund panel cointegration and the Westerlund and Edgerton panel cointegration techniques. The results showed that in the short run, there was a causal relationship from energy consumption to GDP, supporting the growth hypothesis. Omri [18] used the generalized method of moments (GMM) approach to analyze the relationship between $\mathrm{CO}_{2}$ emission, energy consumption and economic growth taking capital and labor as control variables. They analyzed the data over the period 1990-2011 for 14 MENA countries including the six GCC countries. The analysis of both the individual countries and the panel of countries supported the feedback hypothesis in which there is bi-directional causality between energy consumption and economic growth. Salahuddin and Gow [34] examined the relationship between economic growth, energy consumption and $\mathrm{CO}_{2}$ emission in the GCC countries over the period 1980-2012 using the Pedroni panel cointegration technique. The results showed that there was a uni-directional relationship running from economic growth to energy consumption, supporting the conservation hypothesis. Al-Mulali and Ozturk [35] explored the relationship between electricity consumption and economic growth in the GCC countries, taking capital, labor force, exports and imports as control variables. They used the ARDL and the Toda-Yamamoto-Dolado-Lutkepohl techniques over the period 1980-2012 to find the causality relationship. The results showed differences between the GCC countries. For Bahrain and the UAE, there was a bi-directional relationship between 
electricity consumption and economic growth, supporting the feedback hypothesis. On the other hand, for Oman and Qatar, there was a uni-directional relationship running from electricity consumption to economic growth, supporting the growth hypothesis. Finally, for Saudi Arabia and Kuwait, there was no causality relationship between energy consumption and economic growth, supporting the neutrality hypothesis. Jalil [36] investigated the relationship between GDP and energy consumption taking capital stock, employment and trade openness as control variables. He analyzed the data of 29 net energy-importing countries and 19 net energy-exporting countries including the UAE using the Westerlund panel cointegration and the Westerlund and Edgerton panel cointegration techniques over the period 1970-2012. For the net energy-exporting countries, the results showed that there was a bi-directional relationship between energy consumption and economic growth, supporting the feedback hypothesis. Mohammadi and Parvaresh [37] examined the relationship between energy consumption and economic growth for a panel of 14 oil-exporting countries including Saudi Arabia, Oman and Bahrain over the period 1980-2007. They used $\mathrm{CO}_{2}$, exports and urbanization as control variables. The results showed that there was a bi-directional relationship between energy consumption and economic growth, supporting the feedback hypothesis. Salahuddin et al. [40] investigated the relationship between GDP, electricity consumption, $\mathrm{CO}_{2}$ and financial development for the GCC countries. They used the Pedroni panel cointegration technique to analyze the data over the period 1980-2012. The results showed that there was a unidirectional causality running from economic growth to electricity consumption, supporting the conservation hypothesis. Karanfil and Li [41] examined the relationship between electricity consumption and economic growth, taking the net import of electricity and urbanization as control variables for 160 countries including the six GCC countries. They grouped these countries based on the Organization for Economic Cooperation and Development (OECD) membership, income level and region. They used the Pedroni panel cointegration technique to analyze the data over the period 1980-2010. For the Middle East and North Africa panel, the results showed that there was a uni-directional causality running from GDP to electricity consumption supporting the conservation hypothesis. Al-Mulali and Ozturk [43] examined the relationship between industrial GDP, energy consumption, ecological footprint, urbanization, trade openness and political stability and conflict in 14 MENA countries including Saudi Arabia, Kuwait, Oman and the UAE. They analyzed the data over the period 1996-2012 using the Pedroni panel cointegration technique. The results supported the feedback hypothesis in which there is a bi-directional relationship between industrial GDP and energy consumption. Al Iriani and Trabelsi [44] investigated the relationship between GDP, electricity consumption, energy use per unit of GDP, ratio of public spending to GDP and the international oil prices for the six GCC countries. They analyzed the data over the period 1980-2011 using the Johansen multivariate cointegration and the Toda-Yamamoto-Dolado-Lutkepohl techniques. The results were mixed for different countries. For Qatar and Saudi Arabia, the feedback hypothesis was supported. For Bahrain and Kuwait, the conservation hypothesis was supported. For Oman, the growth hypothesis was supported. Finally, for the UAE, the neutrality hypothesis was supported. Kayıkçı and Bildirici [45] estimated the relationship between GDP, electricity consumption and oil rent for 12 MENA countries including Saudi Arabia, Bahrain, Kuwait and Oman. They utilized the ARDL technique to analyze the data in the period 1972-2011. Two hypotheses were supported. For Oman and Saudi Arabia, the conservation hypothesis was supported. On the other hand, for Bahrain and Kuwait, the feedback hypothesis was supported. Ozturk and Al-Mulali [47] investigated the relationship between GDP, natural gas consumption, trade openness, total labor force and gross fixed capital formation in GCC countries. They used the Pedroni panel cointegration technique to analyze the data over the period 1980-2012. The results supported the feedback hypothesis. Magazzino, C. [48] examined the relationship between GDP, electricity consumption, $\mathrm{CO}_{2}$ for the six GCC countries over the period 1960-2013. He used the Johansen-Juselius, the Gregory and Hansen and the ADRL as well as the Toda-Yamamoto-Dolado-Lutkepohl techniques to examine the causal relationship. He found different results for these countries. For Saudi Arabia, the feedback hypothesis was supported. On the other hand, the growth hypothesis was supported for Oman, Kuwait and Qatar. For the 
UAE, the neutrality hypothesis was supported. Finally, for Bahrain, the conservation hypothesis was supported. Ahmed and Azam [49] investigated the relationship between energy consumption and economic growth for 119 countries including Saudi Arabia, Bahrain, Oman and the UAE. They analyzed the data using the Granger causality in frequency domain context. The results supported the neutrality hypothesis for Saudi Arabia, Oman and the UAE. On the other hand, the conservation hypothesis was supported for Bahrain. Magazzino [50] explored the relationship between GDP, energy consumption and $\mathrm{CO}_{2}$ in 10 MENA countries including the six GCC countries. He used the panel generalized method of moments (GMM) to analyze the data over the period 1971-2006. The results supported the growth hypothesis in which there was a uni-directional causality running from energy consumption to economic growth. Osman et al. [12] investigated the relationship between electricity consumption and economic growth in the six GCC countries. They used the Westerlund Panel Cointegration technique to analyze the data over the period 1975-2012. These results supported the feedback hypothesis in which there is a bi-directional relationship between electricity consumption and economic growth. Solarin and Ozturk [52] examined the relationship between natural gas consumption and economic growth for 12 OPEC countries including Saudi Arabia, Kuwait, Qatar and the UAE. They used the panel test proposed by Dumitrescu and Hurlin to analyze the data over the period 1980-2012. The results supported the feedback hypothesis for the OPEC members as a panel. Additional analysis on individual countries showed that the growth hypothesis was supported for Saudi Arabia and Kuwait while the conservation hypothesis was supported for the UAE. Finally, the neutrality hypothesis was supported for Qatar. Ozturk [53] explored the relationship between energy consumption and GDP for 11 MENA countries including Saudi Arabia, Bahrain, Oman and the UAE. He used the Toda-Yamamoto technique to analyze the data in the period 1971-2011. The results supported the conservation hypothesis in Saudi Arabia, the feedback hypothesis in Oman and the UAE and the neutrality hypothesis for Bahrain. Hasanov et al. [54] examined the energy-growth nexus in 10 oil-exporting Eurasian countries including the six GCC countries. They employed two models. The first model used the primary energy consumption while the second model used the residential electricity consumption. The results supported the growth hypothesis in the primary energy consumption model while the neutrality hypothesis was supported in the residential electricity consumption. Antonakakis et al. [55] examined the relationship between energy consumption, $\mathrm{CO}_{2}$ emissions and economic growth for 106 countries including the six GCC countries over the period 1971-2011. They used six models employing six types of energy consumption. The six types were total energy, electricity consumption, oil consumption, renewable energy consumption, natural gas consumption and coal energy consumption. The feedback hypothesis was supported for the total energy and oil consumption models. The conservation hypothesis was supported for the electricity consumption and the renewable energy consumption. The growth hypothesis was supported for the natural gas consumption. Finally, the neutrality hypothesis was supported for the coal energy consumption. Charfeddine and Mrabet [57] investigated the relationship between GDP, energy consumption, ecological footprint, urbanization, political institutional index, fertility rate and life expectancy at birth. They used the Pedroni panel cointegration technique to analyze the data for 15 MENA countries including Saudi Arabia, Qatar, Oman and Kuwait over the period 1975-2007. The results supported the feedback hypothesis. Bekhet et al. [59] examined the relationship between GDP, energy consumption, $\mathrm{CO}_{2}$ and financial development for the six GCC countries. They used the ARDL technique to analyze the data over the period 1980-2011. Different results emerged for different countries. For Saudi Arabia and Qatar, the growth hypothesis was supported. On the other hand, the feedback hypothesis was supported for Oman and the UAE. Finally, the neutrality hypothesis was supported for Bahrain and Kuwait. Al-Mulali and Sab [63] examined the impact of electricity consumption on economic growth taking $\mathrm{CO}_{2}$ emission as a control variable for 12 Middle East counties including the six GCC countries. They used the Pedroni panel cointegration technique to analyze the data over the period 1990-2008. The results supported the feedback hypothesis in which there was a bi-directional relationship between electricity consumption and economic growth. Sekrafi and 
Sghaier [65] investigated the relationship between GDP, energy consumption, $\mathrm{CO}_{2}$, control corruption, investment ratio to GDP and tertiary enrollment rate for 13 MENA countries including Saudi Arabia, Qatar, Oman, Bahrain and the UAE. They used the panel generalized method of moments (GMM) to analyze the data over the period 1984-2012. The results supported the feedback hypothesis. Wang and Fang [66] examined the relationship between GDP, energy consumption, $\mathrm{CO}_{2}$ and urbanization for 170 countries including Saudi Arabia, Bahrain, Oman Kuwait and the UAE. They used the Pedroni panel cointegration technique to analyze the data over the period 1980-2011. They categorized the countries into five panels: global, high income, upper middle income, lower middle income and lower income. The GCC countries were categorized in the high-income panel. For this panel, the results supported the feedback hypothesis. Al-Mulali et al. [67] investigated the relationship between electricity consumption and economic growth for the GCC countries taking domestic investment, labor force, exports and imports as control variables. They used the Pedroni panel cointegration technique to analyze the data over the period 1980-2014. In the short run, there was a uni-directional causality running from GDP to electricity consumption, supporting the conservation hypothesis. Gorus and Aydin [68] investigated the relationship between GDP, energy consumption and $\mathrm{CO}_{2}$ for eight MENA countries including Saudi Arabia, the UAE and Oman. They used the time domain analysis and the frequency domain analysis to analyze the data over the period 1975-2014. Different results emerged. For Saudi Arabia, the feedback hypothesis was supported. On the other hand, the neutrality hypothesis was supported for Oman. Finally, the conservation hypothesis was supported for the UAE. Charfeddine and Kahia [69] examined the relationship between GDP, renewable energy consumption, labor force, capital, $\mathrm{CO}_{2}$ and financial development for 24 MENA countries including all the GCC countries. They used the Westerlund panel cointegration technique to analyze the data over the period 1980-2015. The results supported the growth hypothesis. Table 8 shows the energy-growth articles related to a group of GCC countries. 
Table 8. Energy-growth articles related to a group of GCC countries.

\begin{tabular}{|c|c|c|c|c|c|c|c|c|c|c|c|c|c|}
\hline \multirow[b]{2}{*}{ No } & \multirow[b]{2}{*}{ Study } & \multirow[b]{2}{*}{ Period } & \multirow[b]{2}{*}{ Variables } & \multicolumn{5}{|c|}{ Econometric Methodology } & \multicolumn{4}{|c|}{ Hypothesis } & \multirow[b]{2}{*}{ Note } \\
\hline & & & & $\begin{array}{c}\text { Engle-Granger } \\
\text { and } \\
\text { Johansen-Juselius }\end{array}$ & $\begin{array}{l}\text { ARDL } \\
\text { Bounds } \\
\text { Test }\end{array}$ & $\begin{array}{l}\text { Gregory } \\
\text { and } \\
\text { Hansen, } \\
\text { Hatemi-J } \\
\text { and } \\
\text { Markov } \\
\text { Switching } \\
\text { Approach }\end{array}$ & $\begin{array}{c}\text { Pedroni } \\
\text { Panel } \\
\text { Cointegration } \\
\text { and } \\
\text { Westerlund } \\
\text { Panel } \\
\text { Cointegration } \\
\text { and Other } \\
\text { Panel } \\
\text { Methods }\end{array}$ & $\begin{array}{c}\text { Other } \\
\text { Methods }\end{array}$ & Growth & Conservation & Feedback & Neutral & \\
\hline 1 & Al-Iriani [15] & 1971-2002 & $\begin{array}{l}\text { GDP and } \\
\text { energy } \\
\text { consumption }\end{array}$ & & & & $\sqrt{ }$ & & & $\sqrt{ }$ & & & \\
\hline 2 & Mehrara [19] & 1971-2002 & $\begin{array}{c}\text { GDP and } \\
\text { energy } \\
\text { consumption }\end{array}$ & & & & $\sqrt{ }$ & & & $\sqrt{ }$ & & & \\
\hline \multirow{4}{*}{3} & \multirow{4}{*}{ Squalli [16] } & \multirow{4}{*}{ 1980-2003 } & \multirow{4}{*}{$\begin{array}{c}\text { GDP and } \\
\text { electricity } \\
\text { consumption }\end{array}$} & & \multirow{4}{*}{$\sqrt{ }$} & & & & & & $\sqrt{ }$ & & Saudi Arabia \\
\hline & & & & & & & & & & $\sqrt{ }$ & & & Kuwait \\
\hline & & & & & & & & & & & $\sqrt{ }$ & & Qatar \\
\hline & & & & & & & & & $\sqrt{ }$ & & & & UAE \\
\hline 4 & $\begin{array}{c}\text { Mahadevan } \\
\text { and } \\
\text { Asafu-Adjaye } \\
\text { [20] }\end{array}$ & 1971-2002 & $\begin{array}{l}\text { GDP, energy } \\
\text { consumption } \\
\text { and Prices }\end{array}$ & & & & $\sqrt{ }$ & & & & $\sqrt{ }$ & & \\
\hline \multirow{2}{*}{5} & \multirow{2}{*}{ Mehrara [21] } & \multirow{2}{*}{ 1971-2002 } & \multirow{2}{*}{$\begin{array}{c}\text { GDP and } \\
\text { energy } \\
\text { consumption }\end{array}$} & \multirow{2}{*}{$\sqrt{ }$} & & & & & $\sqrt{ }$ & & & & Saudi Arabia \\
\hline & & & & & & & & & & $\sqrt{ }$ & & & Kuwait \\
\hline 6 & $\begin{array}{l}\text { Narayan and } \\
\text { Smyth [22] }\end{array}$ & 1974-2002 & $\begin{array}{c}\text { GDP, } \\
\text { electricity } \\
\text { consumption } \\
\text { and exports }\end{array}$ & & & & $\sqrt{ }$ & & $\sqrt{ }$ & & & & \\
\hline 7 & $\begin{array}{c}\text { Ozturk et al. } \\
\text { [23] }\end{array}$ & 1971-2005 & $\begin{array}{c}\text { GDP and } \\
\text { energy } \\
\text { consumption }\end{array}$ & & & & $\sqrt{ }$ & & & & $\sqrt{ }$ & & \\
\hline
\end{tabular}


Table 8. Cont.

\begin{tabular}{|c|c|c|c|c|c|c|c|c|c|c|c|c|c|}
\hline \multirow[b]{2}{*}{ No } & \multirow[b]{2}{*}{ Study } & \multirow[b]{2}{*}{ Period } & \multirow[b]{2}{*}{ Variables } & \multicolumn{5}{|c|}{ Econometric Methodology } & \multicolumn{4}{|c|}{ Hypothesis } & \multirow[b]{2}{*}{ Note } \\
\hline & & & & $\begin{array}{l}\text { Engle-Granger } \\
\text { and } \\
\text { Johansen-Juselius }\end{array}$ & $\begin{array}{l}\text { ARDL } \\
\text { Bounds } \\
\text { Test }\end{array}$ & $\begin{array}{l}\text { Gregory } \\
\text { and } \\
\text { Hansen, } \\
\text { Hatemi-J } \\
\text { and } \\
\text { Markov } \\
\text { Switching } \\
\text { Approach }\end{array}$ & $\begin{array}{c}\text { Pedroni } \\
\text { Panel } \\
\text { Cointegration } \\
\text { and } \\
\text { Westerlund } \\
\text { Panel } \\
\text { Cointegration } \\
\text { and Other } \\
\text { Panel } \\
\text { Methods }\end{array}$ & $\begin{array}{c}\text { Other } \\
\text { Methods }\end{array}$ & Growth & Conservation & Feedback & Neutral & \\
\hline 8 & $\begin{array}{c}\text { Al-mulali } \\
{[24]}\end{array}$ & 1980-2009 & $\begin{array}{l}\text { GDP, oil } \\
\text { consumption } \\
\text { and } \mathrm{CO}_{2}\end{array}$ & $\sqrt{ }$ & & & $\sqrt{ }$ & & & & $\sqrt{ }$ & & \\
\hline 9 & $\begin{array}{c}\text { Sadorsky } \\
\text { [25] }\end{array}$ & 1980-2007 & $\begin{array}{l}\text { GDP, energy } \\
\text { consumption } \\
\text { energy price, } \\
\text { trade openness } \\
\text { and country } \\
\text { specific } \\
\text { variable }\end{array}$ & & & & $\sqrt{ }$ & & & & $\sqrt{ }$ & & \\
\hline \multirow[b]{3}{*}{10} & \multirow{3}{*}{$\begin{array}{l}\text { Ozturk and } \\
\text { Acaravci [26] }\end{array}$} & \multirow[b]{3}{*}{ 1971-2006 } & \multirow{3}{*}{$\begin{array}{l}\text { GDP and } \\
\text { electricity } \\
\text { consumption }\end{array}$} & & \multirow[b]{3}{*}{$\sqrt{ }$} & & & & & & & $\sqrt{ }$ & Saudi Arabia \\
\hline & & & & & & & & & & $\sqrt{ }$ & & & Oman \\
\hline & & & & & & & & & & & & & $\begin{array}{l}\text { UAE: } \\
\text { assumptions } \\
\text { violated }\end{array}$ \\
\hline \multirow{4}{*}{11} & \multirow{4}{*}{$\begin{array}{c}\text { Hossein et al. } \\
\text { [27] }\end{array}$} & \multirow{4}{*}{ 1980-2008 } & \multirow{4}{*}{$\begin{array}{l}\text { GDP, energy } \\
\text { consumption } \\
\text { and Prices }\end{array}$} & \multirow{4}{*}{$\sqrt{ }$} & & & & & & $\sqrt{ }$ & & & Saudi Arabia \\
\hline & & & & & & & & & & $\sqrt{ }$ & & & Kuwait \\
\hline & & & & & & & & & & $\sqrt{ }$ & & & Qatar \\
\hline & & & & & & & & & & $\sqrt{ }$ & & & UAE \\
\hline 12 & $\begin{array}{l}\text { Narayan and } \\
\text { Popp [28] }\end{array}$ & 1980-2006 & $\begin{array}{l}\text { GDP and } \\
\text { energy } \\
\text { consumption }\end{array}$ & & & & $\sqrt{ }$ & & & & & $\sqrt{ }$ & \\
\hline
\end{tabular}


Table 8. Cont.

\begin{tabular}{|c|c|c|c|c|c|c|c|c|c|c|c|c|c|}
\hline \multirow[b]{2}{*}{ No } & \multirow[b]{2}{*}{ Study } & \multirow[b]{2}{*}{ Period } & \multirow[b]{2}{*}{ Variables } & \multicolumn{5}{|c|}{ Econometric Methodology } & \multicolumn{4}{|c|}{ Hypothesis } & \multirow[b]{2}{*}{ Note } \\
\hline & & & & $\begin{array}{c}\text { Engle-Granger } \\
\text { and } \\
\text { Johansen-Juselius }\end{array}$ & $\begin{array}{c}\text { ARDL } \\
\text { Bounds } \\
\text { Test }\end{array}$ & $\begin{array}{c}\text { Gregory } \\
\text { and } \\
\text { Hansen, } \\
\text { Hatemi-J } \\
\text { and } \\
\text { Markov } \\
\text { Switching } \\
\text { Approach }\end{array}$ & $\begin{array}{c}\text { Pedroni } \\
\text { Panel } \\
\text { Cointegration } \\
\text { and } \\
\text { Westerlund } \\
\text { Panel } \\
\text { Cointegration } \\
\text { and Other } \\
\text { Panel } \\
\text { Methods }\end{array}$ & $\begin{array}{c}\text { Other } \\
\text { Methods }\end{array}$ & Growth & Conservation & Feedback & Neutral & \\
\hline 13 & $\begin{array}{c}\text { Al-mulali } \\
\text { and Lee [29] }\end{array}$ & 1980-2009 & $\begin{array}{l}\text { GDP, energy } \\
\text { consumption, } \\
\text { financial } \\
\text { development, } \\
\text { urbanization } \\
\text { and total trade }\end{array}$ & & & & $\sqrt{ }$ & & & & $\sqrt{ }$ & & \\
\hline 14 & $\begin{array}{c}\text { Al-mulali } \\
\text { and Tang } \\
\text { [30] }\end{array}$ & 1980-2009 & $\begin{array}{l}\text { GDP, energy } \\
\text { consumption, } \\
\mathrm{CO}_{2} \text { and } \\
\text { foreign direct } \\
\text { investment }\end{array}$ & & & & $\sqrt{ }$ & & & & $\sqrt{ }$ & & \\
\hline 15 & Ozcan [31] & 1990-2008 & $\begin{array}{l}\text { GDP, energy } \\
\text { consumption } \\
\text { and } \mathrm{CO}_{2}\end{array}$ & & & & $\sqrt{ }$ & & & $\sqrt{ }$ & & & \\
\hline 16 & $\begin{array}{c}\text { Damette and } \\
\text { Seghir [32] }\end{array}$ & 1990-2010 & $\begin{array}{c}\text { GDP and } \\
\text { energy } \\
\text { consumption }\end{array}$ & & & & $\sqrt{ }$ & & $\sqrt{ }$ & & & & \\
\hline \multirow{7}{*}{17} & \multirow{7}{*}{ Omri [18] } & \multirow{7}{*}{ 1990-2011 } & \multirow{7}{*}{$\begin{array}{c}\text { GDP, energy } \\
\text { consumption, } \\
\mathrm{CO}_{2} \text {, capital } \\
\text { and labor }\end{array}$} & & & & \multirow{7}{*}{$\sqrt{ }$} & & & & $\sqrt{ }$ & & Panel \\
\hline & & & & & & & & & & & $\sqrt{ }$ & & Saudi Arabia \\
\hline & & & & & & & & & & & $\sqrt{ }$ & & Kuwait \\
\hline & & & & & & & & & & & $\sqrt{ }$ & & Qatar \\
\hline & & & & & & & & & & & $\sqrt{ }$ & & Oman \\
\hline & & & & & & & & & & & $\sqrt{ }$ & & UAE \\
\hline & & & & & & & & & & & $\sqrt{ }$ & & Bahrain \\
\hline
\end{tabular}


Table 8. Cont.

\begin{tabular}{|c|c|c|c|c|c|c|c|c|c|c|c|c|c|}
\hline \multirow[b]{2}{*}{ No } & \multirow[b]{2}{*}{ Study } & \multirow[b]{2}{*}{ Period } & \multirow[b]{2}{*}{ Variables } & \multicolumn{5}{|c|}{ Econometric Methodology } & \multicolumn{4}{|c|}{ Hypothesis } & \multirow[b]{2}{*}{ Note } \\
\hline & & & & $\begin{array}{c}\text { Engle-Granger } \\
\text { and } \\
\text { Johansen-Juselius }\end{array}$ & $\begin{array}{l}\text { ARDL } \\
\text { Bounds } \\
\text { Test }\end{array}$ & $\begin{array}{l}\text { Gregory } \\
\text { and } \\
\text { Hansen, } \\
\text { Hatemi-J } \\
\text { and } \\
\text { Markov } \\
\text { Switching } \\
\text { Approach }\end{array}$ & $\begin{array}{c}\text { Pedroni } \\
\text { Panel } \\
\text { Cointegration } \\
\text { and } \\
\text { Westerlund } \\
\text { Panel } \\
\text { Cointegration } \\
\text { and Other } \\
\text { Panel } \\
\text { Methods }\end{array}$ & $\begin{array}{c}\text { Other } \\
\text { Methods }\end{array}$ & Growth & Conservation & Feedback & Neutral & \\
\hline 18 & $\begin{array}{l}\text { Salahuddin } \\
\text { and Gow } \\
\text { [34] }\end{array}$ & 1980-2012 & $\begin{array}{l}\text { GDP, energy } \\
\text { consumption } \\
\text { and } \mathrm{CO}_{2}\end{array}$ & & & & $\sqrt{ }$ & & & $\sqrt{ }$ & & & \\
\hline \multirow{6}{*}{19} & \multirow{6}{*}{$\begin{array}{c}\text { Al-Mulali } \\
\text { and Ozturk } \\
\text { [35] }\end{array}$} & \multirow{6}{*}{ 1980-2012 } & \multirow{6}{*}{$\begin{array}{c}\text { GDP, } \\
\text { electricity } \\
\text { consumption, } \\
\text { capital, labor } \\
\text { force, exports, } \\
\text { imports }\end{array}$} & & \multirow{6}{*}{$\sqrt{ }$} & & & & & & & $\sqrt{ }$ & Saudi Arabia \\
\hline & & & & & & & & & & & & $\sqrt{ }$ & Kuwait \\
\hline & & & & & & & & & $\sqrt{ }$ & & & & Qatar \\
\hline & & & & & & & & & $\sqrt{ }$ & & & & Oman \\
\hline & & & & & & & & & & & $\sqrt{ }$ & & UAE \\
\hline & & & & & & & & & & & $\sqrt{ }$ & & Bahrain \\
\hline 20 & Jalil [36] & 1970-2012 & $\begin{array}{l}\text { GDP, energy } \\
\text { consumption, } \\
\text { capital stock, } \\
\text { employment } \\
\text { and trade } \\
\text { openness }\end{array}$ & & & & $\sqrt{ }$ & & & & $\sqrt{ }$ & & \\
\hline 21 & $\begin{array}{c}\text { Mohammadi } \\
\text { and } \\
\text { Parvaresh } \\
{[37]}\end{array}$ & 1980-2007 & $\begin{array}{l}\text { GDP, energy } \\
\text { consumption, } \\
\mathrm{CO}_{2} \text {, export } \\
\text { and } \\
\text { urbanization }\end{array}$ & & & & $\sqrt{ }$ & & & & $\sqrt{ }$ & & \\
\hline
\end{tabular}


Table 8. Cont.

\begin{tabular}{|c|c|c|c|c|c|c|c|c|c|c|c|c|c|}
\hline \multirow[b]{2}{*}{ No } & \multirow[b]{2}{*}{ Study } & \multirow[b]{2}{*}{ Period } & \multirow[b]{2}{*}{ Variables } & \multicolumn{5}{|c|}{ Econometric Methodology } & \multicolumn{4}{|c|}{ Hypothesis } & \multirow[b]{2}{*}{ Note } \\
\hline & & & & $\begin{array}{c}\text { Engle-Granger } \\
\text { and } \\
\text { Johansen-Juselius }\end{array}$ & $\begin{array}{c}\text { ARDL } \\
\text { Bounds } \\
\text { Test }\end{array}$ & $\begin{array}{c}\text { Gregory } \\
\text { and } \\
\text { Hansen, } \\
\text { Hatemi-J } \\
\text { and } \\
\text { Markov } \\
\text { Switching } \\
\text { Approach }\end{array}$ & $\begin{array}{c}\text { Pedroni } \\
\text { Panel } \\
\text { Cointegration } \\
\text { and } \\
\text { Westerlund } \\
\text { Panel } \\
\text { Cointegration } \\
\text { and Other } \\
\text { Panel } \\
\text { Methods }\end{array}$ & $\begin{array}{c}\text { Other } \\
\text { Methods }\end{array}$ & Growth & Conservation & Feedback & Neutral & \\
\hline 22 & $\begin{array}{l}\text { Salahuddin, } \\
\text { Gow and } \\
\text { Ozturk [40] }\end{array}$ & 1980-2012 & $\begin{array}{c}\text { GDP, } \\
\text { electricity } \\
\text { consumption, } \\
\mathrm{CO}_{2} \text { and } \\
\text { financial } \\
\text { development }\end{array}$ & & & & $\sqrt{ }$ & & & $\sqrt{ }$ & & & \\
\hline 23 & $\begin{array}{l}\text { Karanfil and } \\
\text { Li [41] }\end{array}$ & 1980-2010 & $\begin{array}{c}\text { GDP, } \\
\text { electricity } \\
\text { consumption, } \\
\text { net import of } \\
\text { electricity and } \\
\text { urbanization }\end{array}$ & & & & $\sqrt{ }$ & & & $\sqrt{ }$ & & & \\
\hline 24 & $\begin{array}{c}\text { Al-Mulali } \\
\text { and Ozturk } \\
{[43]}\end{array}$ & 1996-2012 & $\begin{array}{l}\text { Industrial } \\
\text { GDP, energy } \\
\text { consumption, } \\
\text { ecological } \\
\text { footprint, } \\
\text { urbanization, } \\
\text { trade openness } \\
\text { and political } \\
\text { stability and } \\
\text { conflict }\end{array}$ & & & & $\sqrt{ }$ & & & & $\sqrt{ }$ & & \\
\hline
\end{tabular}


Table 8. Cont.

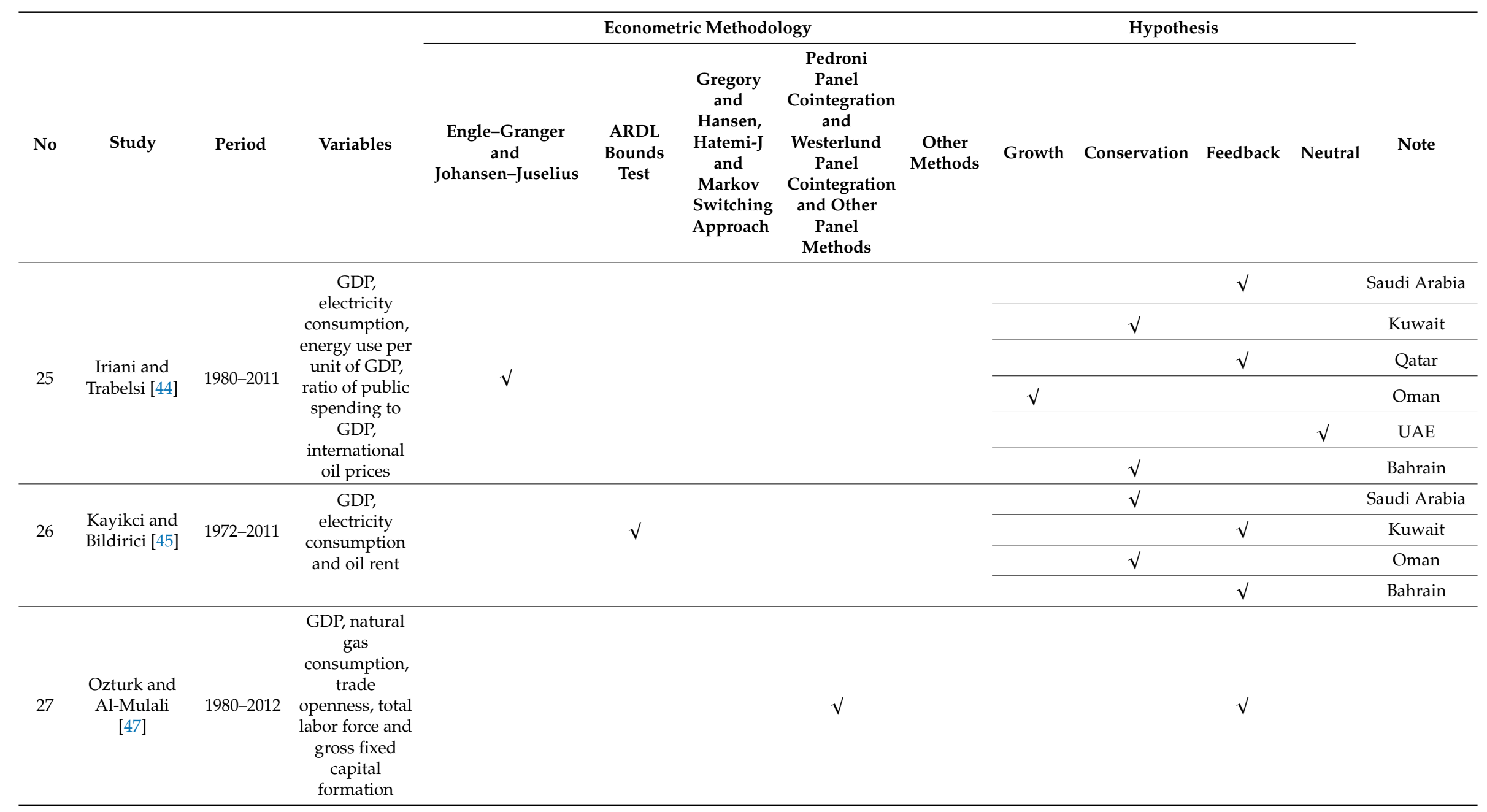


Table 8. Cont

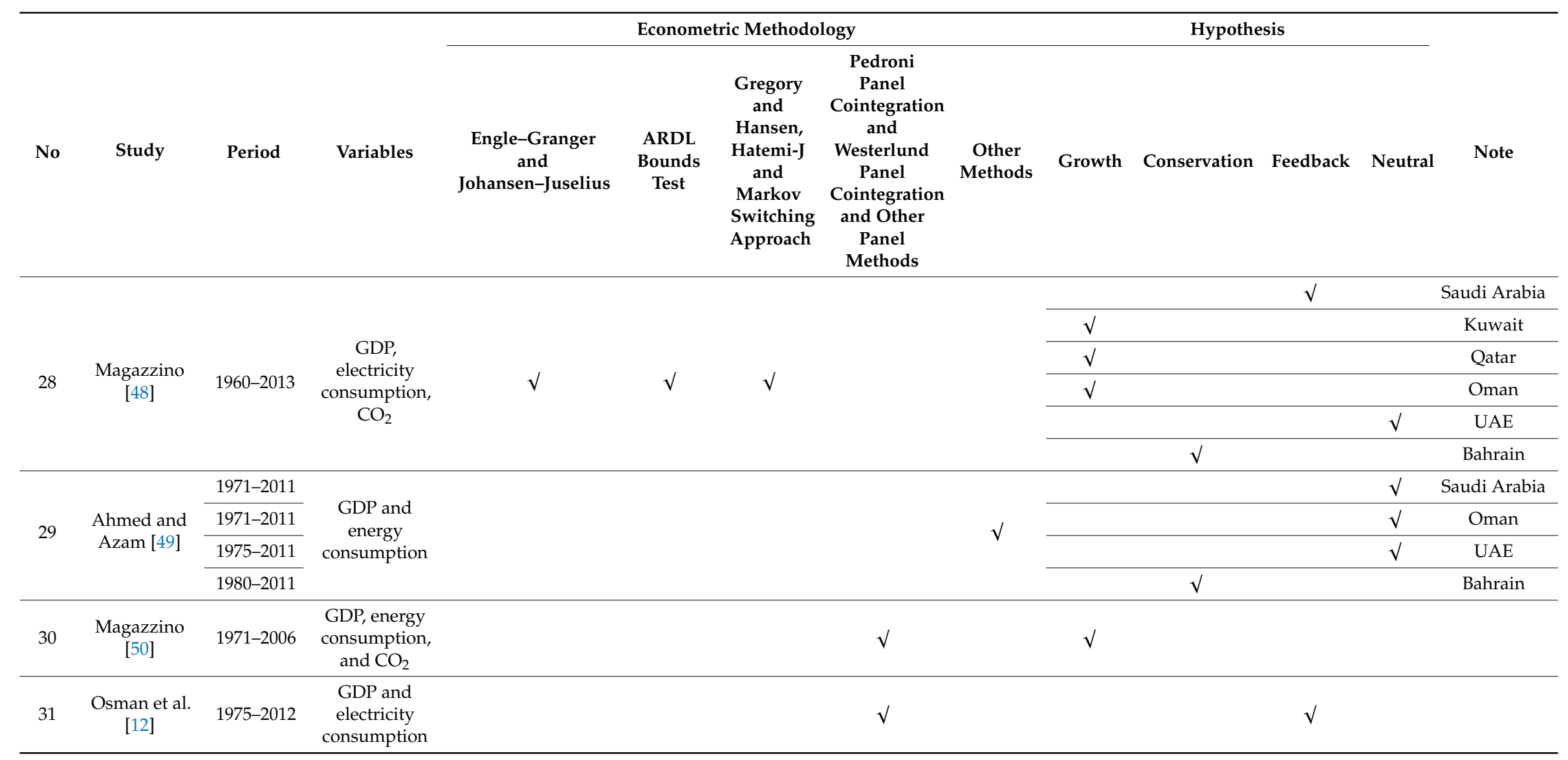


Table 8. Cont

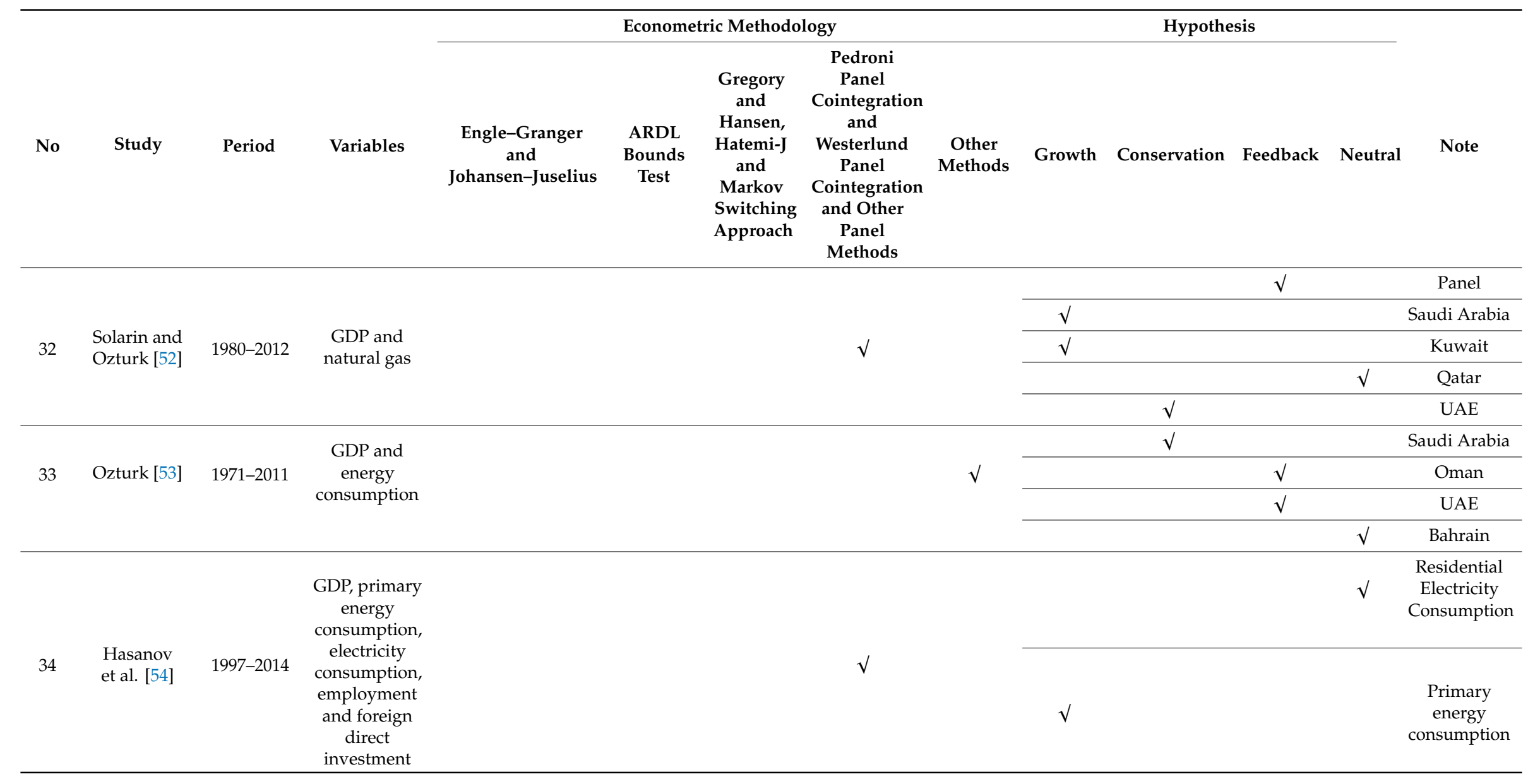


Table 8. Cont.

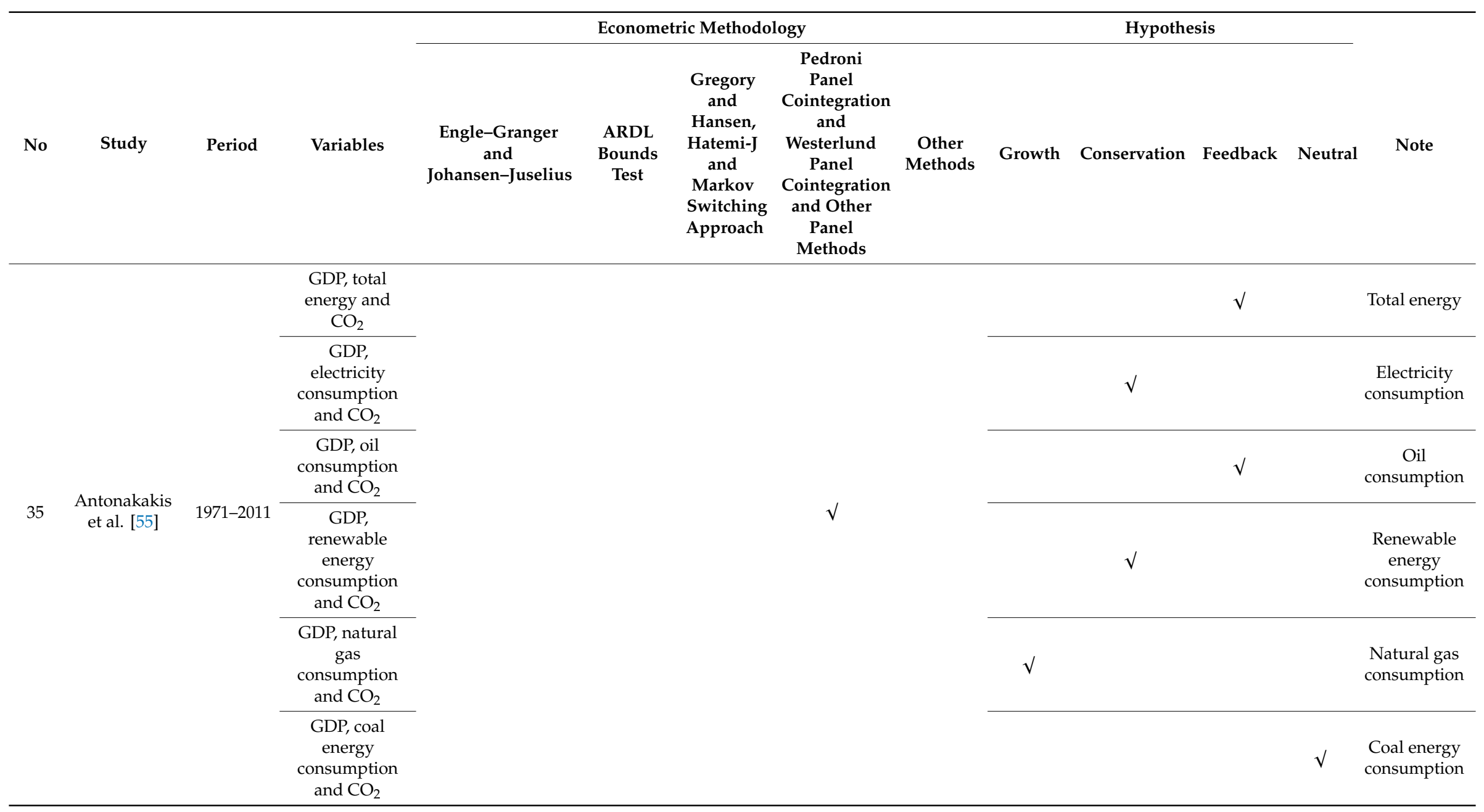


Table 8. Cont.

\begin{tabular}{|c|c|c|c|c|c|c|c|c|c|c|c|c|c|}
\hline \multirow[b]{2}{*}{ No } & \multirow[b]{2}{*}{ Study } & \multirow[b]{2}{*}{ Period } & \multirow[b]{2}{*}{ Variables } & \multicolumn{5}{|c|}{ Econometric Methodology } & \multicolumn{4}{|c|}{ Hypothesis } & \multirow[b]{2}{*}{ Note } \\
\hline & & & & $\begin{array}{c}\text { Engle-Granger } \\
\text { and } \\
\text { Johansen-Juselius }\end{array}$ & $\begin{array}{l}\text { ARDL } \\
\text { Bounds } \\
\text { Test }\end{array}$ & $\begin{array}{l}\text { Gregory } \\
\text { and } \\
\text { Hansen, } \\
\text { Hatemi-J } \\
\text { and } \\
\text { Markov } \\
\text { Switching } \\
\text { Approach }\end{array}$ & $\begin{array}{c}\text { Pedroni } \\
\text { Panel } \\
\text { Cointegration } \\
\text { and } \\
\text { Westerlund } \\
\text { Panel } \\
\text { Cointegration } \\
\text { and Other } \\
\text { Panel } \\
\text { Methods }\end{array}$ & $\begin{array}{l}\text { Other } \\
\text { Methods }\end{array}$ & Growth & Conservation & Feedback & Neutral & \\
\hline 36 & $\begin{array}{c}\text { Charfeddine } \\
\text { and Mrabet } \\
\text { [57] }\end{array}$ & 1975-2007 & $\begin{array}{l}\text { GDP, energy } \\
\text { consumption, } \\
\text { ecological } \\
\text { footprint, } \\
\text { urbanization, } \\
\text { political } \\
\text { institutional } \\
\text { index, fertility } \\
\text { rate and life } \\
\text { expectancy at } \\
\text { birth }\end{array}$ & & & & $\sqrt{ }$ & & & & $\sqrt{ }$ & & \\
\hline \multirow{6}{*}{37} & \multirow{6}{*}{$\begin{array}{c}\text { Bekhet et al. } \\
\text { [59] }\end{array}$} & \multirow{6}{*}{ 1980-2011 } & \multirow{6}{*}{$\begin{array}{l}\text { GDP, energy } \\
\text { consumption, } \\
\mathrm{CO}_{2} \text { and } \\
\text { financial } \\
\text { development }\end{array}$} & & \multirow{6}{*}{$\sqrt{ }$} & & & & $\sqrt{ }$ & & & & Saudi Arabia \\
\hline & & & & & & & & & & & & $\sqrt{ }$ & Kuwait \\
\hline & & & & & & & & & $\sqrt{ }$ & & & & Qatar \\
\hline & & & & & & & & & & & $\sqrt{ }$ & & Oman \\
\hline & & & & & & & & & & & $\sqrt{ }$ & & UAE \\
\hline & & & & & & & & & & & & $\sqrt{ }$ & Bahrain \\
\hline 38 & $\begin{array}{l}\text { Al-Mulali } \\
\text { and Sab [63] }\end{array}$ & 1990-2008 & $\begin{array}{c}\text { GDP, } \\
\text { electricity } \\
\text { consumption } \\
\text { and } \mathrm{CO}_{2}\end{array}$ & & & & $\sqrt{ }$ & & & & $\sqrt{ }$ & & \\
\hline
\end{tabular}


Table 8. Cont.

\begin{tabular}{|c|c|c|c|c|c|c|c|c|c|c|c|c|c|}
\hline \multirow[b]{2}{*}{ No } & \multirow[b]{2}{*}{ Study } & \multirow[b]{2}{*}{ Period } & \multirow[b]{2}{*}{ Variables } & \multicolumn{5}{|c|}{ Econometric Methodology } & \multicolumn{4}{|c|}{ Hypothesis } & \multirow[b]{2}{*}{ Note } \\
\hline & & & & $\begin{array}{l}\text { Engle-Granger } \\
\text { and } \\
\text { Johansen-Juselius }\end{array}$ & $\begin{array}{l}\text { ARDL } \\
\text { Bounds } \\
\text { Test }\end{array}$ & $\begin{array}{l}\text { Gregory } \\
\text { and } \\
\text { Hansen, } \\
\text { Hatemi-J } \\
\text { and } \\
\text { Markov } \\
\text { Switching } \\
\text { Approach }\end{array}$ & $\begin{array}{l}\text { Pedroni } \\
\text { Panel } \\
\text { Cointegration } \\
\text { and } \\
\text { Westerlund } \\
\text { Panel } \\
\text { Cointegration } \\
\text { and Other } \\
\text { Panel } \\
\text { Methods }\end{array}$ & $\begin{array}{c}\text { Other } \\
\text { Methods }\end{array}$ & Growth & Conservation & Feedback & Neutral & \\
\hline 39 & $\begin{array}{l}\text { Sekrafi and } \\
\text { Sghaier [65] }\end{array}$ & 1984-2012 & $\begin{array}{c}\text { GDP, energy } \\
\text { consumption, } \\
\mathrm{CO}_{2} \text {, control } \\
\text { corruption, } \\
\text { investment } \\
\text { ratio to GDP, } \\
\text { and tertiary } \\
\text { enrollment } \\
\text { rate }\end{array}$ & & & & $\sqrt{ }$ & & & & $\sqrt{ }$ & & \\
\hline 40 & $\begin{array}{l}\text { Wang et al. } \\
\text { [66] }\end{array}$ & 1980-2011 & $\begin{array}{l}\text { GDP, energy } \\
\text { consumption, } \\
\mathrm{CO}_{2} \text { and } \\
\text { urbanization }\end{array}$ & & & & $\sqrt{ }$ & & & & $\sqrt{ }$ & & \\
\hline 41 & $\begin{array}{l}\text { Al-Mulali } \\
\text { et al. [67] }\end{array}$ & 1980-2014 & $\begin{array}{c}\text { GDP, } \\
\text { electricity } \\
\text { consumption, } \\
\text { domestic } \\
\text { investment, } \\
\text { labor force, } \\
\text { exports and } \\
\text { imports }\end{array}$ & & & & $\sqrt{ }$ & & & $\sqrt{ }$ & & & \\
\hline
\end{tabular}


Table 8. Cont.

\begin{tabular}{|c|c|c|c|c|c|c|c|c|c|c|c|c|c|}
\hline \multirow[b]{2}{*}{ No } & \multirow[b]{2}{*}{ Study } & \multirow[b]{2}{*}{ Period } & \multirow[b]{2}{*}{ Variables } & \multicolumn{5}{|c|}{ Econometric Methodology } & \multicolumn{4}{|c|}{ Hypothesis } & \multirow[b]{2}{*}{ Note } \\
\hline & & & & $\begin{array}{l}\text { Engle-Granger } \\
\text { and } \\
\text { Johansen-Juselius }\end{array}$ & $\begin{array}{c}\text { ARDL } \\
\text { Bounds } \\
\text { Test }\end{array}$ & $\begin{array}{l}\text { Gregory } \\
\text { and } \\
\text { Hansen, } \\
\text { Hatemi-J } \\
\text { and } \\
\text { Markov } \\
\text { Switching } \\
\text { Approach }\end{array}$ & $\begin{array}{l}\text { Pedroni } \\
\text { Panel } \\
\text { Cointegration } \\
\text { and } \\
\text { Westerlund } \\
\text { Panel } \\
\text { Cointegration } \\
\text { and Other } \\
\text { Panel } \\
\text { Methods }\end{array}$ & $\begin{array}{c}\text { Other } \\
\text { Methods }\end{array}$ & Growth & Conservation & Feedback & Neutral & \\
\hline \multirow{3}{*}{42} & \multirow{3}{*}{$\begin{array}{l}\text { Gorus and } \\
\text { Aydin [68] }\end{array}$} & \multirow{3}{*}{ 1975-2014 } & \multirow{3}{*}{$\begin{array}{l}\text { GDP, energy } \\
\text { consumption } \\
\text { and } \mathrm{CO}_{2}\end{array}$} & & & & & \multirow{3}{*}{$\sqrt{ }$} & & & $\sqrt{ }$ & & Saudi Arabia \\
\hline & & & & & & & & & & & & $\sqrt{ }$ & Oman \\
\hline & & & & & & & & & & $\sqrt{ }$ & & & UAE \\
\hline 43 & $\begin{array}{l}\text { Charfeddine } \\
\text { and Kahia } \\
\text { [69] }\end{array}$ & 1980-2015 & $\begin{array}{c}\text { GDP, } \\
\text { renewable } \\
\text { energy } \\
\text { consumption, } \\
\text { labor force, } \\
\text { capital, } \mathrm{CO}_{2} \\
\text { and financial } \\
\text { development }\end{array}$ & & & & $\sqrt{ }$ & & $\sqrt{ }$ & & & & \\
\hline
\end{tabular}




\subsection{Summary of the Analysis}

Table 9 shows the percentage of the supported hypotheses in individual GCC countries broken down into studies of individual countries, panels of countries and combined. The number of observations for the studies in individual countries was 81 while it was 186 for the studies on a panel of countries. The total observations was 267 . Although there was no hypothesis that was supported more than $50 \%$ to be considered a dominating hypothesis, it could be observed that the feedback hypothesis was ranked number 1 with a percent of $43 \%$ in the combined studies. This was followed by the conservation hypothesis with $26 \%$ and the growth hypothesis $18 \%$. The least supported hypothesis was the neutrality hypothesis with a percentage of $13 \%$. As a group, the feedback and the growth hypotheses were supported in $61 \%$ of the observations. A similar observation can be seen for the individual countries. The feedback and the growth hypotheses were supported $61 \%$ for Saudi Arabia, $58 \%$ for Kuwait, $66 \%$ for Qatar, $63 \%$ for Oman, $63 \%$ for the UAE and $56 \%$ for Bahrain. The results were expected as the GCC countries share similar economic and natural energy resources.

Table 9. Summary of the four hypotheses among the GCC Countries.

\begin{tabular}{|c|c|c|c|c|c|}
\hline & \multirow{2}{*}{$\begin{array}{c}\text { No of } \\
\text { Observations }\end{array}$} & \multicolumn{4}{|c|}{ Individual } \\
\hline & & Growth & Conservation & Feedback & Neutral \\
\hline Saudi Arabia & 24 & $33 \%$ & $21 \%$ & $21 \%$ & $25 \%$ \\
\hline Kuwait & 11 & $18 \%$ & $36 \%$ & $27 \%$ & $18 \%$ \\
\hline Qatar & 11 & $45 \%$ & $9 \%$ & $36 \%$ & $9 \%$ \\
\hline Oman & 10 & $30 \%$ & $20 \%$ & $30 \%$ & $20 \%$ \\
\hline UAE & 16 & $13 \%$ & $19 \%$ & $50 \%$ & $19 \%$ \\
\hline Bahrain & 9 & $0 \%$ & $33 \%$ & $44 \%$ & $22 \%$ \\
\hline \multirow[t]{3}{*}{ Total } & 81 & $25 \%$ & $22 \%$ & $33 \%$ & $20 \%$ \\
\hline & \multirow{2}{*}{$\begin{array}{c}\text { No of } \\
\text { Observations }\end{array}$} & \multicolumn{4}{|c|}{ Panel } \\
\hline & & Growth & Conservation & Feedback & Neutral \\
\hline Saudi Arabia & 35 & $17 \%$ & $26 \%$ & $49 \%$ & $9 \%$ \\
\hline Kuwait & 30 & $17 \%$ & $27 \%$ & $47 \%$ & $10 \%$ \\
\hline Qatar & 27 & $15 \%$ & $30 \%$ & $44 \%$ & $11 \%$ \\
\hline Oman & 33 & $15 \%$ & $27 \%$ & $48 \%$ & $9 \%$ \\
\hline UAE & 32 & $16 \%$ & $28 \%$ & $47 \%$ & $9 \%$ \\
\hline Bahrain & 29 & $14 \%$ & $31 \%$ & $45 \%$ & $10 \%$ \\
\hline \multirow[t]{3}{*}{ Total } & 186 & $16 \%$ & $28 \%$ & $47 \%$ & $10 \%$ \\
\hline & No of & \multicolumn{4}{|c|}{ Combined } \\
\hline & Observations & Growth & Conservation & Feedback & Neutral \\
\hline Saudi Arabia & 59 & $24 \%$ & $24 \%$ & $37 \%$ & $15 \%$ \\
\hline Kuwait & 41 & $17 \%$ & $29 \%$ & $41 \%$ & $12 \%$ \\
\hline Qatar & 38 & $24 \%$ & $24 \%$ & $42 \%$ & $11 \%$ \\
\hline Oman & 43 & $19 \%$ & $26 \%$ & $44 \%$ & $12 \%$ \\
\hline UAE & 48 & $15 \%$ & $25 \%$ & $48 \%$ & $13 \%$ \\
\hline Bahrain & 38 & $11 \%$ & $32 \%$ & $45 \%$ & $13 \%$ \\
\hline Total & 267 & $18 \%$ & $26 \%$ & $43 \%$ & $13 \%$ \\
\hline
\end{tabular}

Waheed et. al. (2019) [7] conducted a survey of literature on the relationship between economic growth, energy consumption and carbon emission. They found that for the developing countries, 
energy consumption caused economic growth, supporting the growth hypothesis. Sarwar et al. (2017) [72] and Shahbaz et al. (2017) [73] investigated the relationship between electricity consumption, oil prices and economic growth on a global perspective. Sarwar et al. (2017) [72] used the panel data of 210 countries categorized by income, OECD, regional level, renewable energy consumption level and oil export/import countries. They found that different hypotheses were supported for different groups of countries with respect to the relationship between electricity consumption and economic growth. For example, they found that the growth hypothesis was supported for Middle Eastern and North African (MENA) countries. Moreover, the feedback hypothesis was supported for oil-exporting countries. GCC countries, the focus of our study, belong to these two groups and our general conclusion that the growth hypothesis and the feedback hypothesis were supported $61 \%$ is in agreement with this study. Similarly, Shahbaz et al. (2017) [73] included the data of 157 countries categorized by income, OECD and region. Their study supported the feedback hypothesis for the developing countries. These countries depend heavily on electricity consumption for economic growth. Economic growth in GCC countries has been tremendous in recent decades and it was mainly fueled by their richness in natural resources of oil and gas. GCC countries are members of the United Nations High Level Political Forum on Sustainable Development, which oversee the implementation of 17 sustainable development goals (SDG) set out by the United Nations General Assembly. For readers information, goal 12 is "Sustainable Consumption and Production", and goal 13 is "Climate Action". GCC countries officially adopted these goals and integrated them into their national institutional development framework, budget and national governance structure as evidenced by the voluntary national review (VNR) reports to the United Nations High Level Political Forum on Sustainable Development (available online: https://sustainabledevelopment.un.org/memberstates). Furthermore, GCC countries started to seriously implement strategies for generating and using electricity that are compatible with sustainable development (Al-Sarihi, 2018) [74]. Therefore, GCC countries should expand their investment in renewable energy sources such as solar and other renewable energy sources in order to supply cheap and sustainable energy that will lead to long-term economic growth. The benefit of focusing on solar and other environmentally friendly sources of energy is obvious. It will ensure continuous economic growth without harming the environment. Over the longer term, the existing use of fossil fuels will go down and eventually will be replaced by the other alternative sources of energy.

\section{Conclusions}

This survey reviewed the literature on the causal relationship between energy consumption and economic growth for the six GCC countries. The survey included 59 studies published in 18 different journals spanning the period 2006-2019. The survey divided the existing studies into two categories: ones dealing with individual countries and other ones analyzing the data of more than one country. Our survey revealed that there was no one dominating hypothesis. All four hypotheses were supported among the different GCC countries. As stated in previous literature review studies, different hypotheses being supported could be attributed to the differences in selected variables, the specifications of models, time spans and econometric approaches, etc. [1-6]. Yet, as we were expecting, our analysis showed that the majority of studies supported the growth or the feedback hypotheses (61\% combined). This leads us to draw an important conclusion regarding the relationship between energy consumption and economic growth: when it comes to the literature on the design and implementation of energy policies and programs in GCC countries, the focus has been on the supply and availability of energy for the expansion and growth of developmental activities. Compared with economies of advanced counties, where energy efficiency and energy conservation programs, technologies and community-participatory initiatives are the drivers for energy, policymakers in GCC countries have to attune their energy policies to their localized conditions. Furthermore, GCC countries should be cautious about implementing conservation policies.

In addition to the above conclusions, additional points can be inferred from the analysis. It was observed that more studies on individual countries are needed. For example, there was no single study 
found in this literature review about the energy-growth nexus for Oman. Moreover, there was only one study identified for Bahrain and one for Kuwait. This scarcity of country-specific studies may encourage researchers to conduct studies on these specific countries. Moreover, the majority of studies considered aggregate data, e.g., the total energy consumption, total electricity consumption and total oil consumption. To get better understanding, future studies may include the energy consumption of specific sectors such as the residential sector, industrial sector and the service sector Studying the individual sectors may help decision makers better understand the causality relationship between energy consumption and economic growth for specific sectors so energy conservation policies can be applied differently to different sectors.

Author Contributions: Conceptualization, M.A.; Methodology, M.A., F.M., H.Q.-U., and A.K.; Formal analysis, M.A.; Investigation, M.A. and F.M.; Resources, M.A. and A.K.; Data curation, M.A.; Writing-Original draft preparation, M.A. and F.M.; Writing-Review and editing, H.Q.-U. and A.K.; Project administration, M.A.; funding acquisition, M.A. All authors have read and agreed to the published version of the manuscript.

Funding: This research received no external funding.

Acknowledgments: The authors would like to acknowledge King Fahd University of Petroleum \& Minerals (KFUPM) for its support. We also thank Ionut Spanu, Assistant Editor-Sustainability Journal, for handling the peer review process and providing constructive comments. We thank also the three anonymous reviewers for their comments that have improved the manuscript.

Conflicts of Interest: The authors declare no conflict of interest.

\section{References}

1. Payne, J.E. A Survey of the Electricity Consumption-Growth Literature. Appl. Energy 2010, 87, 723-731. [CrossRef]

2. Ozturk, I. A Literature Survey on Energy-Growth Nexus. Energy Policy 2010, 38, 340-349. [CrossRef]

3. Menegaki, A.N. On Energy Consumption and GDP Studies, A Meta-Analysis of the Last Two Decades. Renew. Sustain. Energy Rev. 2014, 29, 31-36. [CrossRef]

4. Kalimeris, P.; Richardson, C.; Bithas, K. A Meta-Analysis Investigation of the Direction of the Energy-GDP Causal Relationship: Implications for the Growth-Degrowth Dialogue. J. Clean. Prod. 2014, 67, 1-13. [CrossRef]

5. Omri, A. An International Literature Survey on Energy-Economic Growth Nexus: Evidence from Country-Specific Studies. Renew. Sustain. Energy Rev. 2014, 38, 951-959. [CrossRef]

6. Tiba, S.; Omri, A. Literature Survey on the Relationships between Energy, Environment and Economic Growth. Renew. Sustain. Energy Rev. 2017, 69, 1129-1146. [CrossRef]

7. Waheed, R.; Sarwar, S.; Wei, C. The Survey of Economic Growth, Energy Consumption and Carbon Emission. Energy Rep. 2019, 5, 1103-1115. [CrossRef]

8. Narayan, S. Predictability within the Energy Consumption-Economic Growth Nexus: Some Evidence from Income and Regional Groups. Econ. Model. 2016, 54, 515-521. [CrossRef]

9. Murdock, H.E.; Adib, R.; Lins, C.; Guerra, F.; Misra, A.; Vickery, L.; Collier, U.; Le Feuvre, P.; Bianco, E.; Mueller, S.; et al. Renewable Energy Policies in a Time of Transition; IRENA: Abu Dhabi, UAE, 2018.

10. Kuwait Energy Outlook; Kuwait Institute for Scientific Research: Kuwait City, Kuwait, 2019.

11. Al-Badi, A.; Almubarak, I. Growing Energy Demand in the GCC Countries. Arab J. Basic Appl. Sci. 2019, 26, 488-496. [CrossRef]

12. Osman, M.; Gachino, G.; Hoque, A. Electricity Consumption and Economic Growth in the GCC Countries: Panel Data Analysis. Energy Policy 2016, 98, 318-327. [CrossRef]

13. Kraft, J.; Kraft, A. On the relationship between energy and GNP. J. Energy Dev. 1978, 3, 401-403.

14. Sweidan, O.D. Energy Consumption and Real Output: New Evidence from the UAE. OPEC Energy Rev. 2012, 36, 287-300. [CrossRef]

15. Al-Iriani, M.A. Energy-GDP Relationship Revisited: An Example from GCC Countries Using Panel Causality. Energy Policy 2006, 34, 3342-3350. [CrossRef]

16. Squalli, J. Electricity Consumption and Economic Growth: Bounds and Causality Analyses of OPEC Members. Energy Econ. 2007, 29, 1192-1205. [CrossRef] 
17. Alkhathlan, K.; Javid, M. Energy Consumption, Carbon Emissions and Economic Growth in Saudi Arabia: An Aggregate and Disaggregate Analysis. Energy Policy 2013, 62, 1525-1532. [CrossRef]

18. Omri, A. $\mathrm{CO}_{2}$ Emissions, Energy Consumption and Economic Growth Nexus in MENA Countries: Evidence from Simultaneous Equations Models. Energy Econ. 2013, 40, 657-664. [CrossRef]

19. Mehrara, M. Energy Consumption and Economic Growth: The Case of Oil Exporting Countries. Energy Policy 2007, 35, 2939-2945. [CrossRef]

20. Mahadevan, R.; Asafu-Adjaye, J. Energy Consumption, Economic Growth and Prices: A Reassessment Using Panel VECM for Developed and Developing Countries. Energy Policy 2007, 35, 2481-2490. [CrossRef]

21. Mehrara, M. Energy-GDP Relationship for Oil-Exporting Countries: Iran, Kuwait and Saudi Arabia. OPEC Rev. 2007, 31, 1-16. [CrossRef]

22. Narayan, P.K.; Smyth, R. Multivariate Granger Causality between Electricity Consumption, Exports and GDP: Evidence from a Panel of Middle Eastern Countries. Energy Policy 2009, 37, 229-236. [CrossRef]

23. Ozturk, I.; Aslan, A.; Kalyoncu, H. Energy Consumption and Economic Growth Relationship: Evidence from Panel Data for Low and Middle Income Countries. Energy Policy 2010, 38, 4422-4428. [CrossRef]

24. Al-Mulali, U. Oil Consumption, $\mathrm{CO}_{2}$ Emission and Economic Growth in MENA Countries. Energy 2011, 36, 6165-6171. [CrossRef]

25. Sadorsky, P. Trade and Energy Consumption in the Middle East. Energy Econ. 2011, 33, 739-749. [CrossRef]

26. Ozturk, I.; Acaravci, A. Electricity Consumption and Real GDP Causality Nexus: Evidence from ARDL Bounds Testing Approach for 11 MENA Countries. Appl. Energy 2011, 88, 2885-2892. [CrossRef]

27. Hossein, A.; Yazdan, G.F.; Ehsan, A.G. The Relationship between Energy Consumption, Energy Prices and Economic Growth: Case Study (OPEC Countries). OPEC Energy Rev. 2012, 36, 272-286. [CrossRef]

28. Narayan, P.K.; Popp, S. The Energy Consumption-Real GDP Nexus Revisited: Empirical Evidence from 93 Countries. Econ. Model. 2012, 29, 303-308. [CrossRef]

29. Al-Mulali, U.; Lee, J.Y. Estimating the Impact of the Financial Development on Energy Consumption: Evidence from the GCC (Gulf Cooperation Council) Countries. Energy 2013, 60, 215-221. [CrossRef]

30. Al-Mulali, U.; Tang, C.F. Investigating the Validity of Pollution Haven Hypothesis in the Gulf Cooperation Council (GCC) Countries. Energy Policy 2013, 60, 813-819. [CrossRef]

31. Ozcan, B. The Nexus between Carbon Emissions, Energy Consumption and Economic Growth in Middle East Countries: A Panel Data Analysis. Energy Policy 2013, 62, 1138-1147. [CrossRef]

32. Damette, O.; Seghir, M. Energy as a Driver of Growth in Oil Exporting Countries? Energy Econ. 2013, 37, 193-199. [CrossRef]

33. Shahbaz, M.; Sbia, R.; Hamdi, H.; Ozturk, I. Economic Growth, Electricity Consumption, Urbanization and Environmental Degradation Relationship in United Arab Emirates. Ecol. Indic. 2014, 45, 622-631. [CrossRef]

34. Salahuddin, M.; Gow, J. Economic Growth, Energy Consumption and $\mathrm{CO}_{2}$ Emissions in Gulf Cooperation Council Countries. Energy 2014, 73, 44-58. [CrossRef]

35. Al-Mulali, U.; Ozturk, I. Are Energy Conservation Policies Effective without Harming Economic Growth in the Gulf Cooperation Council Countries? Renew. Sustain. Energy Rev. 2014, 38, 639-650. [CrossRef]

36. Jalil, A. Energy-Growth Conundrum in Energy Exporting and Importing Countries: Evidence from Heterogeneous Panel Methods Robust to Cross-Sectional Dependence. Energy Econ. 2014, 44, 314-324. [CrossRef]

37. Mohammadi, H.; Parvaresh, S. Energy Consumption and Output: Evidence from a Panel of 14 Oil-Exporting Countries. Energy Econ. 2014, 41, 41-46. [CrossRef]

38. Sbia, R.; Shahbaz, M.; Hamdi, H. A Contribution of Foreign Direct Investment, Clean Energy, Trade Openness, Carbon Emissions and Economic Growth to Energy Demand in UAE. Econ. Model. 2014, 36, 191-197. [CrossRef]

39. Hamdi, H.; Sbia, R.; Shahbaz, M. The Nexus between Electricity Consumption and Economic Growth in Bahrain. Econ. Model. 2014, 38, 227-237. [CrossRef]

40. Salahuddin, M.; Gow, J.; Ozturk, I. Is the Long-Run Relationship between Economic Growth, Electricity Consumption, Carbon Dioxide Emissions and Financial Development in Gulf Cooperation Council Countries Robust? Renew. Sustain. Energy Rev. 2015, 51, 317-326. [CrossRef]

41. Karanfil, F.; Li, Y. Electricity Consumption and Economic Growth: Exploring Panel-Specific Differences. Energy Policy 2015, 82, 264-277. [CrossRef] 
42. Alshehry, A.S.; Belloumi, M. Energy Consumption, Carbon Dioxide Emissions and Economic Growth: The Case of Saudi Arabia. Renew. Sustain. Energy Rev. 2015, 41, 237-247. [CrossRef]

43. Al-Mulali, U.; Ozturk, I. The Effect of Energy Consumption, Urbanization, Trade Openness, Industrial Output, and the Political Stability on the Environmental Degradation in the MENA (Middle East and North African) Region. Energy 2015, 84, 382-389. [CrossRef]

44. Iriani, M.A.A.; Trabelsi, M. The Economic Impact of Phasing out Energy Consumption Subsidies in GCC Countries. J. Econ. Bus. 2016, 87, 35-49. [CrossRef]

45. Kayıkçı, F.; Bildirici, M. Economic Growth and Electricity Consumption in GCC and MENA Countries. S. Afr. J. Econ. 2014, 83, 303-316. [CrossRef]

46. Belloumi, M.; Alshehry, A. Sustainable Energy Development in Saudi Arabia. Sustainability 2015, 7, 5153-5170. [CrossRef]

47. Ozturk, I.; Al-Mulali, U. Natural Gas Consumption and Economic Growth Nexus: Panel Data Analysis for GCC Countries. Renew. Sustain. Energy Rev. 2015, 51, 998-1003. [CrossRef]

48. Magazzino, C. The Relationship between Real GDP, $\mathrm{CO}_{2}$ Emissions, and Energy Use in the GCC Countries: A Time Series Approach. Cogent Econ. Finance 2016, 4, 1152729. [CrossRef]

49. Ahmed, M.; Azam, M. Causal Nexus between Energy Consumption and Economic Growth for High, Middle and Low Income Countries Using Frequency Domain Analysis. Renew. Sustain. Energy Rev. 2016, 60, 653-678. [CrossRef]

50. Magazzino, C. $\mathrm{CO}_{2}$ Emissions, Economic Growth, and Energy Use in the Middle East Countries: A Panel VAR Approach. Energy Sour. Part B Econ. Plan. Policy 2016, 11, 960-968. [CrossRef]

51. Charfeddine, L.; Khediri, K.B. Financial Development and Environmental Quality in UAE: Cointegration with Structural Breaks. Renew. Sustain. Energy Rev. 2016, 55, 1322-1335. [CrossRef]

52. Solarin, S.A.; Ozturk, I. The Relationship between Natural Gas Consumption and Economic Growth in OPEC Members. Renew. Sustain. Energy Rev. 2016, 58, 1348-1356. [CrossRef]

53. Ozturk, F. Energy Consumption-GDP Causality in MENA Countries. Energy Sour. Part B Econ. Plan. Policy 2017, 12, 231-236. [CrossRef]

54. Hasanov, F.; Bulut, C.; Suleymanov, E. Review of Energy-growth Nexus: A Panel Analysis for Ten Eurasian Oil Exporting Countries. Renew. Sustain. Energy Rev. 2017, 73, 369-386. [CrossRef]

55. Antonakakis, N.; Chatziantoniou, I.; Filis, G. Energy Consumption, CO 2 Emissions, and Economic Growth: An Ethical Dilemma. Renew. Sustain. Energy Rev. 2017, 68, 808-824. [CrossRef]

56. Mahalik, M.K.; Babu, M.S.; Loganathan, N.; Shahbaz, M. Does Financial Development Intensify Energy Consumption in Saudi Arabia? Renew. Sustain. Energy Rev. 2017, 75, 1022-1034. [CrossRef]

57. Charfeddine, L.; Mrabet, Z. The Impact of Economic Development and Social-Political Factors on Ecological Footprint: A Panel Data Analysis for 15 MENA Countries. Renew. Sustain. Energy Rev. 2017, 76, 138-154. [CrossRef]

58. Charfeddine, L. The Impact of Energy Consumption and Economic Development on Ecological Footprint and $\mathrm{CO}_{2}$ Emissions: Evidence from a Markov Switching Equilibrium Correction Model. Energy Econ. 2017, 65, 355-374. [CrossRef]

59. Bekhet, H.A.; Matar, A.; Yasmin, T. $\mathrm{CO}_{2}$ Emissions, Energy Consumption, Economic Growth, and Financial Development in GCC Countries: Dynamic Simultaneous Equation Models. Renew. Sustain. Energy Rev. 2017, 70, 117-132. [CrossRef]

60. Charfeddine, L.; Al-Malk, A.Y.; Korbi, K.A. Is It Possible to Improve Environmental Quality without Reducing Economic Growth: Evidence from the Qatar Economy. Renew. Sustain. Energy Rev. 2018, 82, 25-39. [CrossRef]

61. Salahuddin, M.; Alam, K.; Ozturk, I.; Sohag, K. The Effects of Electricity Consumption, Economic Growth, Financial Development and Foreign Direct Investment on $\mathrm{CO}_{2}$ Emissions in Kuwait. Renew. Sustain. Energy Rev. 2018, 81, 2002-2010. [CrossRef]

62. Xu, Z.; Baloch, M.A.; Danish; Meng, F.; Zhang, J.; Mahmood, Z. Nexus between Financial Development and $\mathrm{CO}_{2}$ Emissions in Saudi Arabia: Analyzing the Role of Globalization. Environ. Sci. Pollut. Res. 2018, 25, 28378-28390. [CrossRef]

63. Al-Mulali, U.; Sab, C.N.B.C. Electricity Consumption, $\mathrm{CO}_{2}$ Emission, and Economic Growth in the Middle East. Energy Sour. Part B Econ. Plan. Policy 2018, 13, 257-263. [CrossRef]

64. Al-Mulali, U.; Sab, C.N.B.C. Energy Consumption, $\mathrm{CO}_{2}$ Emissions, and Development in the UAE. Energy Sour. Part B Econ. Plan. Policy 2018, 13, 231-236. [CrossRef] 
65. Sekrafi, H.; Sghaier, A. Examining the Relationship Between Corruption, Economic Growth, Environmental Degradation, and Energy Consumption: A Panel Analysis in MENA Region. J. Knowl. Econ. 2018, 9, 963-979. [CrossRef]

66. Wang, S.; Li, G.; Fang, C. Urbanization, Economic Growth, Energy Consumption, and $\mathrm{CO}_{2}$ Emissions: Empirical Evidence from Countries with Different Income Levels. Renew. Sustain. Energy Rev. 2018, 81, 2144-2159. [CrossRef]

67. Al-Mulali, U.; Tang, C.F.; Tan, B.W.; Ozturk, I. The Nexus of Electricity Consumption and Economic Growth in Gulf Cooperation Council Economies: Evidence from Non-Stationary Panel Data Methods. Geosyst. Eng. 2019, 22, 40-47. [CrossRef]

68. Gorus, M.S.; Aydin, M. The Relationship between Energy Consumption, Economic Growth, and $\mathrm{CO}_{2}$ Emission in MENA Countries: Causality Analysis in the Frequency Domain. Energy 2019, 168, 815-822. [CrossRef]

69. Charfeddine, L.; Kahia, M. Impact of Renewable Energy Consumption and Financial Development on $\mathrm{CO}_{2}$ Emissions and Economic Growth in the MENA Region: A Panel Vector Autoregressive (PVAR) Analysis. Renew. Energy 2019, 139, 198-213. [CrossRef]

70. Akadiri, A.C.; Akadiri, S.S.; Gungor, H. The Role of Natural Gas Consumption in Saudi Arabias Output and Its Implication for Trade and Environmental Quality. Energy Policy 2019, 129, 230-238. [CrossRef]

71. Alsaedi, Y.H.; Tularam, G.A. The Relationship between Electricity Consumption, Peak Load and GDP in Saudi Arabia: A VAR Analysis. Math. Comput. Simul. 2019, 175, 164-178. [CrossRef]

72. Sarwar, S.; Chen, W.; Waheed, R. Electricity Consumption, Oil Price and Economic Growth: Global Perspective. Renew. Sustain. Energy Rev. 2017, 76, 9-18. [CrossRef]

73. Shahbaz, M.; Sarwar, S.; Chen, W.; Malik, M.N. Dynamics of Electricity Consumption, Oil Price and Economic Growth: Global Perspective. Energy Policy 2017, 108, 256-270. [CrossRef]

74. Al-Sarihi, A. Prospects for Climate Change Integration into GCC Economic Diversification Strategies; LSE Middle East Centre Paper Series 20; LSE Middle East Centre: London, UK, 2018.

(C) 2020 by the authors. Licensee MDPI, Basel, Switzerland. This article is an open access article distributed under the terms and conditions of the Creative Commons Attribution (CC BY) license (http://creativecommons.org/licenses/by/4.0/). 